\title{
Tactics for Transforming the Housing Structure, New Housing Models Incision of the City, Connecting the Urban Fragments of the City of Skopje
}

\author{
Aleksandar Petanovski ${ }^{*}$ \\ Faculty of Architecture - Skopje, Ss Cyril and Methodius University of Skopje, Skopje, Republic of Macedonia
}

Citation: Petanovski A. [Tactics for Transforming the Housing Structure, New Housing Models Incision of the City, Connecting 2015 Jan 24: 2015:10002. SEE [Macedonian] http://dx.doi.org/10.3889/seejad.2015.10002

Key words: Incision; urban fragments; city-mosaic; housing; connection; bridge; transformation; communication

"Correspondence: Aleksandar Petanovski. Faculty of Architecture - Skopje, Ss Cyril and Methodius University of aleksandar petanovski@hotmailcom

Received: 16-Dec-2014; Revised: 23-Dec-2014; Accepted: 14-Jan-2015; Published: 24-Jan-2015

Copyright: ๑ 2015 Aleksandar Petanovski. This is an openaccess article distributed under the terms of the Creative Commons Attribution License, which permits unrestricted use, distiginat author and source are inedity Competing Interests: The author have declared that no

\section{Abstract}

As witnesses of the dynamic and increased extension and densification of the development of our urban spaces, we need a re-qualification of the values that we as members and professionals create in the urban environment in which we live in.

Skopje is a fragmented city, consisted of a diverse morphological and social context and the permanence and transformation of the urban structure is in a constant conflict. Defining new tactics for transformation of the housing structure and presenting new models for housing is the new challenge that the city will be facing in order to create a homogeneous morphological and ideological identity. The research of the possible transformation offers a method which can be applied and adapted on versatile urban contexts and provide upgrade and integration of the program and volume of the city.

In this research, the linear structure is chosen as a basic morphological element. Towards a better understanding of this formal act of positioning an axis, we first have to understand the political and social events from historical, social and cultural aspect. In the first part, the research is based on examples of the historical genesis of linear structures and examples regarding the research of linear structures or cities and in the second part, closing in on the study area of the city of Skopje and the east-west axis of development and growth of the city (the master plan of the architect Ludek Kubes in 1948). The method of incision is presented in the third part, incision or cutting through, from a theoretical aspect and superposing a linear structure as a tactic for transforming the urban morphology. The urban fragments are a distinctive phenomenon of the city of Skopje; the principals of informal transformation may offer a strategy that will succeed to unify and connect the contradictory condition, which is a consequence of different ideas, implementations and non-realization of plans and also of political, economic and other social factors. 
Универзитет “Св.Кирил и Методиј” - Архитектонски фракултет, Скопје

$$
\text { МАГИСТЕРСКИ ТРУД }
$$

TEMA: Тактики на трансформирање на станбената текстура, нови модели на домување

\begin{abstract}
НАСЛОВ: Инцизија (расекување) на градот, поврзување на урбаните фрагменти на примерот на Скопје
\end{abstract}

текстуален дел

Ментор: Профр. Д-р. Минас Бакалчев Кандидат: Александар Петановски 6614

Скопје, 2013 
Комисија:

Ментор: Проф. Д-р. Минас Бакалчев

Претседател на комисија: Проф. Д-р Анета Христова-Поповска

Профр. Д-р. Мирослав Грчев

Доц. М-р. Елизабета Касапова

Дата на одбрана: јули, 2013 


\section{Апстракт:}

Како сведоци на се подинамичниот развој на урбаните средини, потребна ни е реквалификација на вредностите кои ги создаваме како жители и како професионалци во урбана средина во која живееме во XXI век.

Скопје е фрагментиран град кој содржи различни временски, морфолошки и социјални контексти и перманентноста и променливоста на урбаната структура е во постојан конфоликт. Обидот да се дефинираат тактики за трансформирање на станбената структура и претставување на нови модели на домување е предизвик со кој што ќе мора да се соочи градот со цел да се создаде еден хомоген идентитет од морфолошки, но и од идеолошки карактер. Истражувањето и претставувањето на една таква можна трансформација преку овој труд нуди метода која може да се примени и прилагоди на различни урбани контексти и да овозможи програмско и просторно надоградување и интегрирање на градот.

Во истражувањето како базична морфолошка основа земена е линиската структура. За да се разбере еден ваков формален акт на поставување на аксијала, мора да се проучат и разберат политичките и општествените случувања од историски, социјално-културен аспект. Во првиот дел од истражувањето претставена е таа историска генеза на линеарната структура и примери од истражувања за линеарни мега-структури или градови, за потоа да преминеме на истражениот случај, Скопје и ширењето по оска запад-исток (урбанистичкиот план на архитектот Лудек Кубеш од 1948 година). Во третиот дел на истражувањето претставен е методот на инцизија / расекување од теоретски аспект и суперпонирање на линеарна структура на примерот на Скопје како тактики за трансформација на урбаната морфологија. Урбаните фрагменти се дистинктивен френомен на градот Скопје; принципите на неформална трансформација може да понудат стратегија која ќе успее да ја поврзе противречната состојба кој е последица на различните идеи, реализации и нереализации, а воедно и политичките, општествените и временските фактори.

Клучни зборови: инцизија, урбан фрагмент, град - мозаик, поврзување, мост, трансорормација, комуникација, рекреација 


\section{Содржина:}

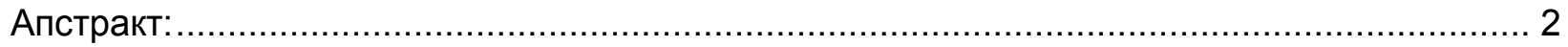

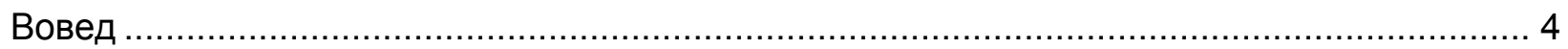

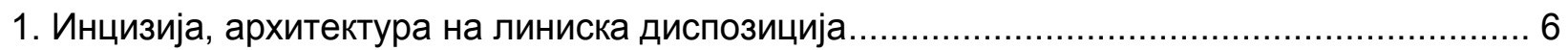

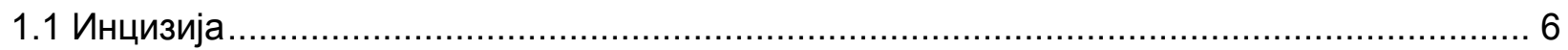

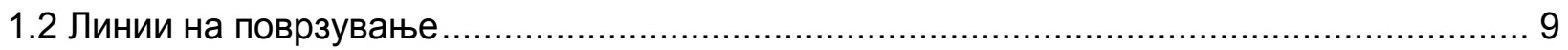

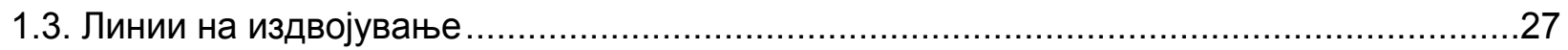

2. Скопје - од радијален кон линиски град ……........................................................

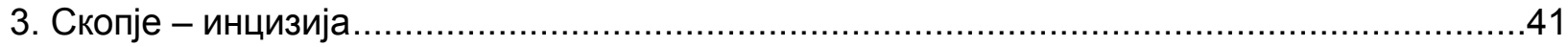

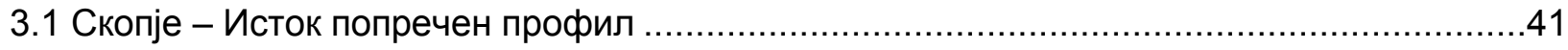

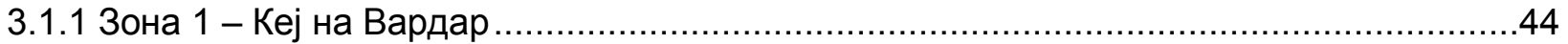

3.1.2 Зона 2 - Неформални станбени џебови, населба “Ќерамидница” .............................46

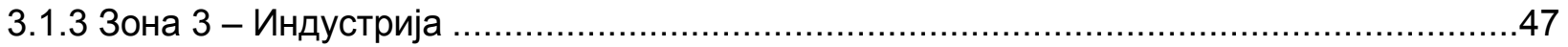

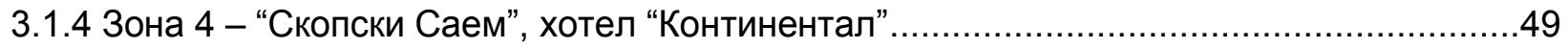

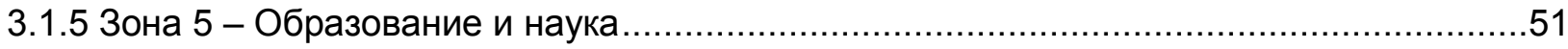

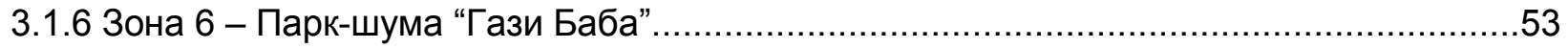

3.2 Скопје - Исток инцизија, презентација на методот на интервенција ...........................54

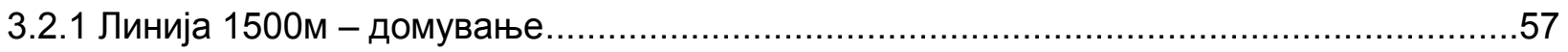

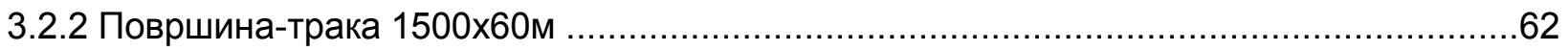

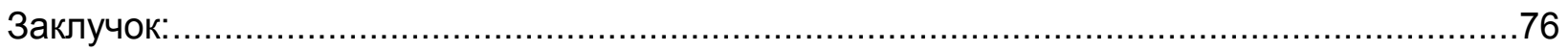

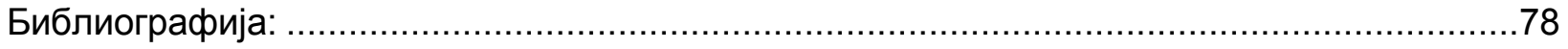

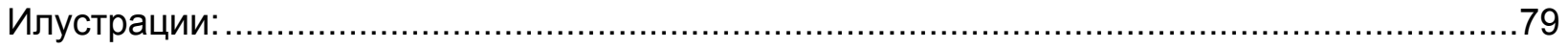




\section{Вовед}

Современиот град е град на противречности, различни идеи и фризички структури, визии и ре-визии, утопии и дистопии. Но токму таквата сложена и противречна состојба на градот на почетокот на XXI век, после еден век на модернизации, не повикува на едно потемелно истражување на ефектите и феномените на модернизацијата. Движејќи се помеѓу крајностите, она што е слабост можеме да го направиме предност, она што е обично да стане необично, она што е секојдневно да стане оригинално.

Резултат на проектот на модернизацијата на градот Скопје е неговата фрагментирана состојба. Различните надворшни парчиња на градот создаваат еден своевиден урбан архипелаг, составен од различни често противречни, конфрликтни положби. Како овој град кој е составен од разнородни урбани фррагменти, станбени џебови, можеме да го соочиме со сопствениот плурален потенцијал?

Цел на проектот се современите трансформации на станбената структура во просторно и социјално фрагментирани зони. На избран пример од Скопје ова истражување ќе понуди различни модели на интегрирање и трансформирање, зголемување на просторен програмски капацитет, со внесување на нови животни вредности.

Преку постапката на инцизија (расекување) на градот и суперпонирање на линеарни формации возможно е програмско и просторно надградување и 
истовремено поврзување на различните просторни програмски положби на градот. На тој начин се создава една нова просторна конфигурација, колективна форма, која се однесува на конкретните урбани морфологии, но истовремено опстојува независно. Преку расекување на градот теоретски, можеме да ги дефинираме односите помеѓу различните зони на линискиот град, да ги согледаме можностите за трансформација преку процесот на просторно и програмско интегрирање на истите и можноста да воведеме нови станбени модели на живеење.

Локација на предметот на проектната задача:

Источниот дел на градот Скопје, пресек низ неколку зони; од север кон југ: паркшума “Гази Баба”, зона-образование, зона-Скопски Саем, зона-индустрија, зонакеј на река Вардар.

Предмет на проектот е станбената текстура на избран сектор од градот.

Пост-воената обнова на градот ја трансформираше фрормата на градот, од концентрично-радијална кон линиска. Но додека линиската екстензија на градот, во подолжниот правец, ја изразуваше неговата нова функционалистичка конструкција, во попречниот правец на градот, воедно значеше негово испрекинување, просторен-програмски дисконтинуитет. Ова истражување се однесува на попречниот сектор на градот составен од траката на образование, индустрија, спонтани станбени џебови, крајбрежната зона на реката Вардар. На кој начин овие разнородни програмски траки можат да се интегрираат? 


\section{1. Инцизија, архитектура на линиска диспозиција}

\section{1 Инцизија}

v. лат. Circumcido

1. Хируршки рез низ кожа или месо

2. Процес низ кој нешто се сече

Поимот инцизија или расекување претставен во општа форма означува процес во кој физички се врши сечење на дефиниран елемент. Во зависност од природата на процесот, овој поим се употребува во сите сфрери на науката како: медицина, биологија, археологија, економија, уметност, архитектура итн.

Надвор од рамките на примарната природа во која се употребува - медицината, истиот поим може да укажува на некој вид на раздвоеност, дисконтинуитет, јасна поделеност, а исто така истиот процес може да се спореди со медицинскиот, само од различен, теоретски аспект, како процес преку кој се претставува поглед од нова перспектива, диференцирање и согледување на составните елементи на предметот на истражувње и оценување на истите.

Од аспект на архитектура овој поим има повеќе значења; може да означува строга, силна линија од објект која го сече воздухот и просторот околу него, може директно да упатува на пресек на објектот со земјиштето, пресек само низ земјиштето, пресек низ самиот објект или повеќе структури. 
Поимот инцизија или расекување, без разлика од каков аспект го истражуваме, има линиска природа. Ако повторно се вратиме на архитектурата и урбанизмот, линиската конфригурација е во пресек или со градското ткаење или со природата. Во теоретски аспект овој поим ќе го следиме со систематско истражување на промените на линиските дистрибуции во архитектурата, дефинирани како туку го вклучува комплетниот френомен на транзиција од поединечен објект до град.

Со Атинската повелба на СІАМ (1933 година) биле дефинирани зоните на функционалниот град:

1. Чисто одвоена зона на железнички сообраќај

2. Зона за производство и комунални претпријатија, со сродни научни, технички и образовни институции

3. Зелена зона или тампон зона со главните патишта

4. Резиденцијална зона, социјални институции, резиденцијални објекти

5. Парковска зона

6. Зона за агрикултура, градини, фрарми

Со паралелно поставување на овие зони се создава систем во кој сите фрагменти придонесуваат за комплетирање на целината, но сепак се јасно диференцирани и независни една од друга. Линеарниот град претставува една прагматична формација на сценарија кои просторно се претставени во линеарна , причинскополедователна структура. Кога се работи за линеарни формации кои се суперпонираат врз урбана морфологија, како што е случај во претпоставката на овој магистерски труд, тие создаваат интеракција помеѓу различни делови на 
градот со што би се извршила просторна и програмска интеграција и различни можни начини на трансформација на одделни фрагменти од градот.

- Од теоретски аспект на овој магистерски труд, поимот се однесува на систематско истражување на линеарното расекување на пост-транзициско Скопје, на почетокот на XIX век. Се истражуваат зоните на линеарната екстензија на градот, новиот програмски и морфолошки карактер како и границите кои ги дефинираат и создаваат дисконтинуитет во спротивниот правец. Во таа смисла, постапката на инцизија/расекување е метода на делување и реинтегрирање во фрагментираниот град. 


\section{2 Линии на поврзување}

Еден од главните аспекти на линиската дистрибуција се однесува на поврзувањето. Оваа постапка претставува поврзување на две дистинктивни точки во простор, како и континуирано поврзување на сите точки кои лежат на една линија. Истата претставува и математичка дефинција за отсечка.

Планот на Рим од Папата Сикстус V (Sixtus V), реализиран во 1590 година, е пример на редесринирање на градот преку поврзување на клучните точки во него. Предложена е длабинска структура на организација со правци кои ги поврзуваат главните простори и структури во градот. Класичниот Рим беше збирка од монументални структури во кои не беше застапена хиерархија на просторните соодноси и моделот на поврзување и циркулација. Во планот на Папата Сикстус $\mathrm{V}$ е предложен нов начин на размислување за градот со артикулирање на циркулацијата / аксијалноста како организациона структура. Репрезентацијата на планот укажува на приматот на вклучувањето на движењето во просторот, наместо претставувањето на градот преку изолирани, статички елементи, тој е претставен како структурален скелет на линии и референтни точки во кои се конвергираат и сечат линиите. Примарна е артикулацијата на искуството на движењето долж оваа аксијала. 


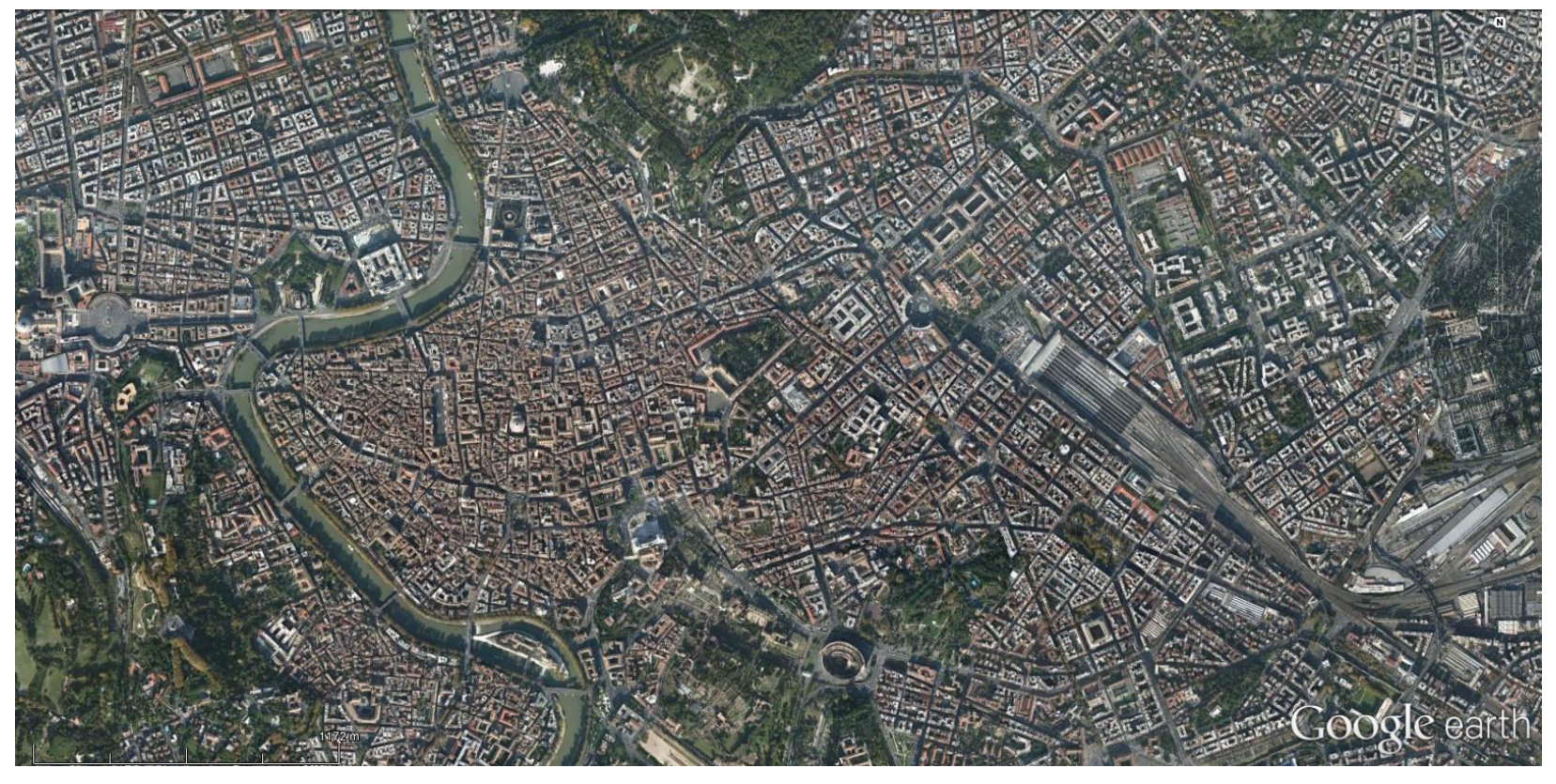

Сл. 1 Pим (Google Earth слика) 


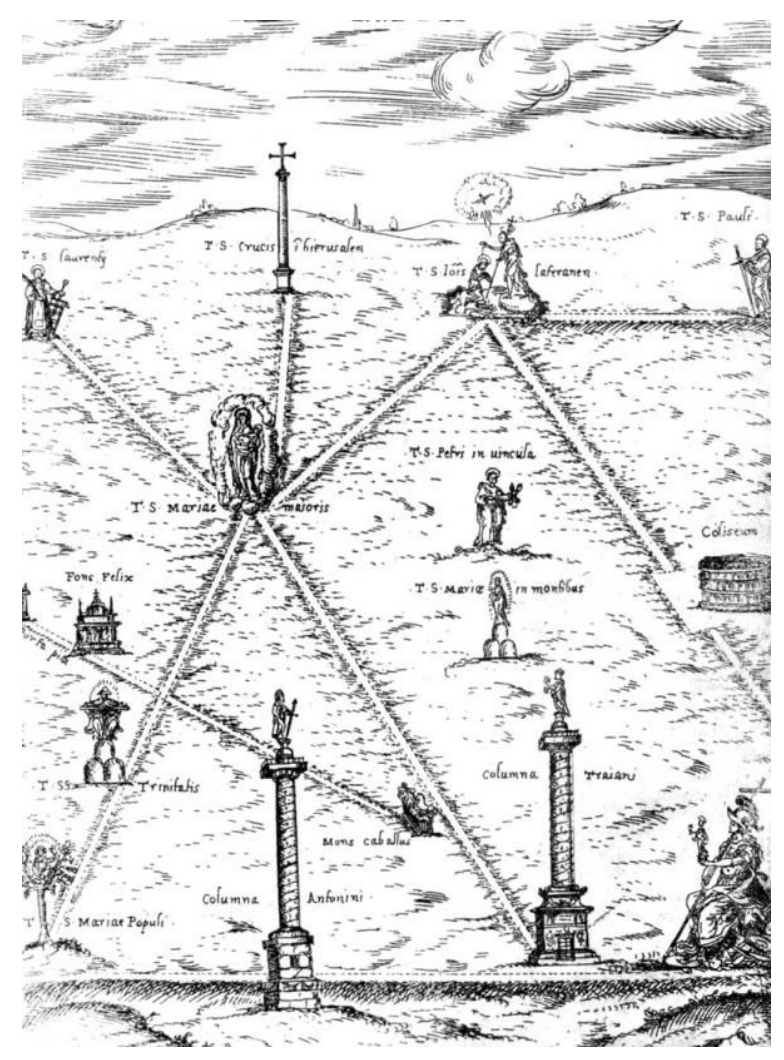

Сл. 2 Мапа на Рим од Г.Ф. Бордино, (1588)

Со технолошките иновации биле овозможени нови и побрзи видови на транспорт, со што растојанието помеѓу две дестинации значително се намалило. Во планирањето на новите градови главен предизвик била инфраструктурата за транспортот, односно автомобилските патишта, железничките пруги и поврзувањето на истите со урбаната морфологија во еден заеднички систем. Урбаните планови кои биле планирани со линиска формација содржеле серија на функционално специјализирани паралелни сектори. Исто така бил користен и текот на некоја река за да доминантните ветрови дуваат од резиденцијалниот кон индустрискиот сектор.

Во контекст на индустриската парадигма од XIX-XX век, линискиот концепт станува ефикасно средство за организација како на производниот процес, така и 
на целото општество. Еден од првите линиски модели, се однесува за екстензијата на градот Мадрид од архитектот Артуро Сорија Мата (Arturo Soria y Mata) од 1882 година. Во планот на линеарниот град (Ciudad Lineal), предлага промена на формата на градот од радјална, центар со периферија, во линеарни секции на инфраструктура, пат, железница, гас, вода, како една оптимална линија на која би се приклучиле другите содржини и намени како домување, комерцијални и индустриски програми.

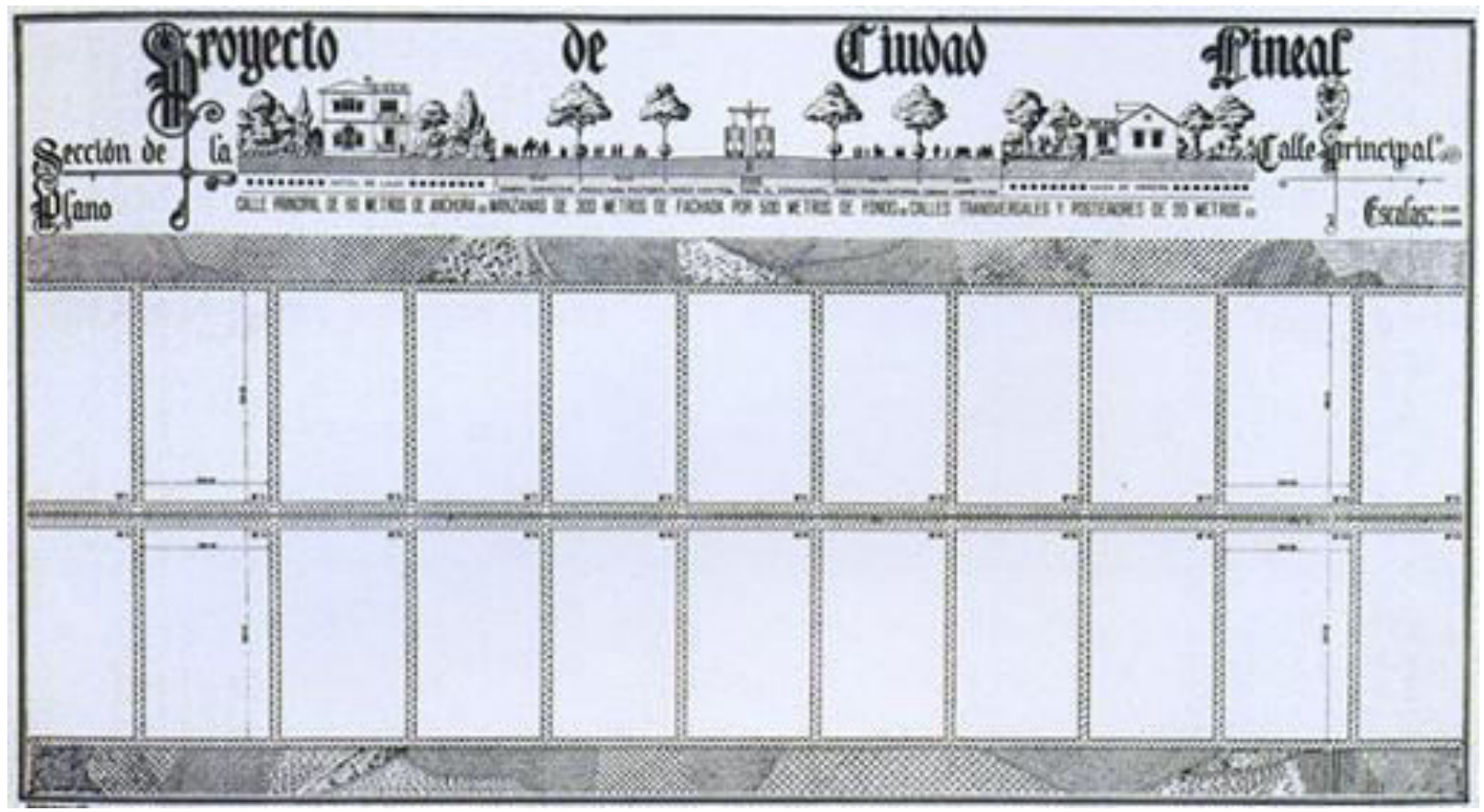

Сл. 3 Линеарна екстензија на Мадрид, А.Сорија Mama, (1882) 
Еден од најрадикалните екстензии на моделот на линиската дистрибуција се однесува на пост-револуционерниот период во Советскиот Сојуз. Во теоретската дебата на дезурбанистите, суштествена идеја е дека градовите се симболи на капиталистичката експлоатација на трудот. Како што напиша Никола Миљутин во книгата Соцгород (1930), “постојните градови се создадени во интерес на владеачките класи, непријателите на пролетеријатот". Тргнувајќ од идеолошката критика на капитализмот, Миљутин развива проект како модел на теоријата и праксата на просторното планирање, советскиот-линеарен град. Тоа создаде модел на еден рационален и економичен град кој делува како интерференција помеѓу руралното и урбаното и претставува една ефикасна обединета целина, еден функционален линиски систем (functional-assembly-line system). Во таa смисла овој линиски систем требаше да ги минимализира транспортните давачки во време и пари.

Линеарниот град е една кон-урбана формација сочинета од серија функционални и специјализирани паралелни сектори, ригорозно планирана диспозиција, која според Миљутин, никогаш не треба да биде променета. Генерално, градот треба да биде позициониран паралелно на река и треба да биде изграден така што доминантните ветрови дуваат од резиденцијалните кон индустриските зони. Различните секции на градот се: 1 . целосно одделена зона за железничкиот сообраќај, 2. зона за производство заедно со научни, технички и образовни институции, 3. зелен појас како тампон зона, со големи автопати, 4. 
резиденцијална зона, социјални институции, 5. парк зона, 6. зона за агрикултура и градини.

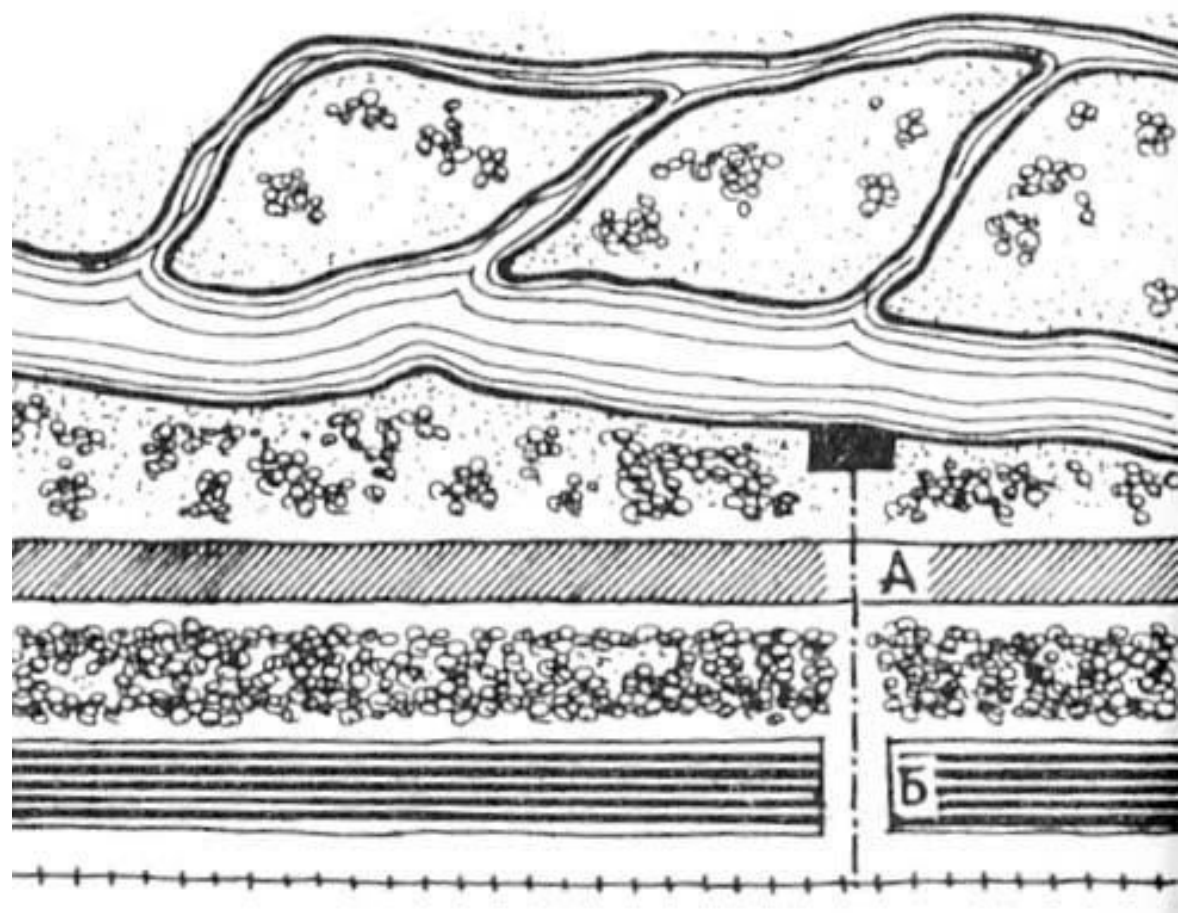

Сл. 4 Линеарен град на Н. Миљутин

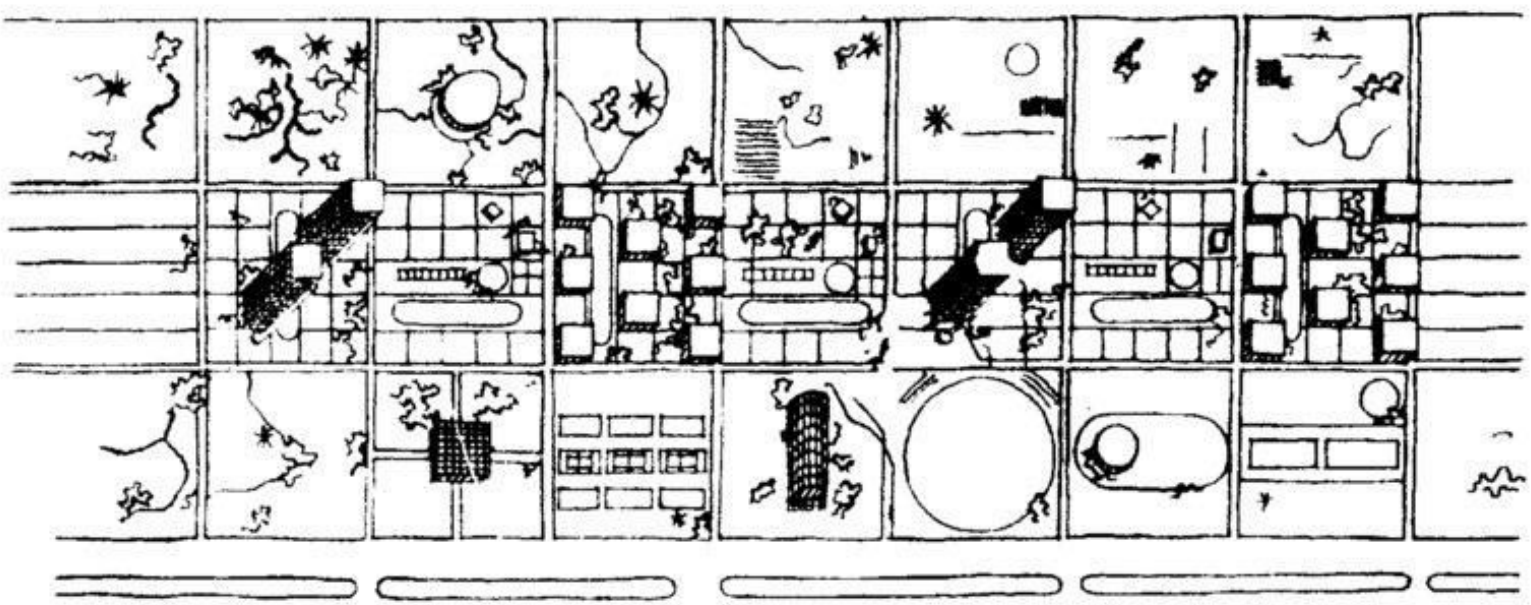

Сл. 5 План за градот Магнитогорск, И. Леонидов (1930) 
Во триесетите години на дваесетиот век, линеарната дистрибуција како основа за драматично редефинирање на фрормата на градот во однос на постојната урбана морфологија и топографија на градот е најсугестивно покажана во проектот на Ле Корбизје за Алжир (1932 година). Рецентните критики на овој зафат укажуваат на двојниот аспект, додека на архитектонско ниво е прототип на симбиозата на инфраструктурата и станбената програма во сооднос на географијата на пределот, на политичко ниво се чита како колонијалистичка екстензија на Франција во однос на северна Африка. Овој став се изразува во низа цртежи на Ле Корбизје каде аксијала која оди од север кон југ ги поврзува Франција, преку медитеранот, Алжир и продолжува и понатаму. Скиците на облакодерите ги индицираат градовите во едно трансгеографско поврзување низ моделот на новата архитектура и урбанизам.

На архитектонско ниво овој проект ги антиципира идејата на мегаформата, прво, како единство на архитектурата и инфраструктурата, второ, како колективна форма во која основните станбени единици се променливи независно од основната структурална рамка. 


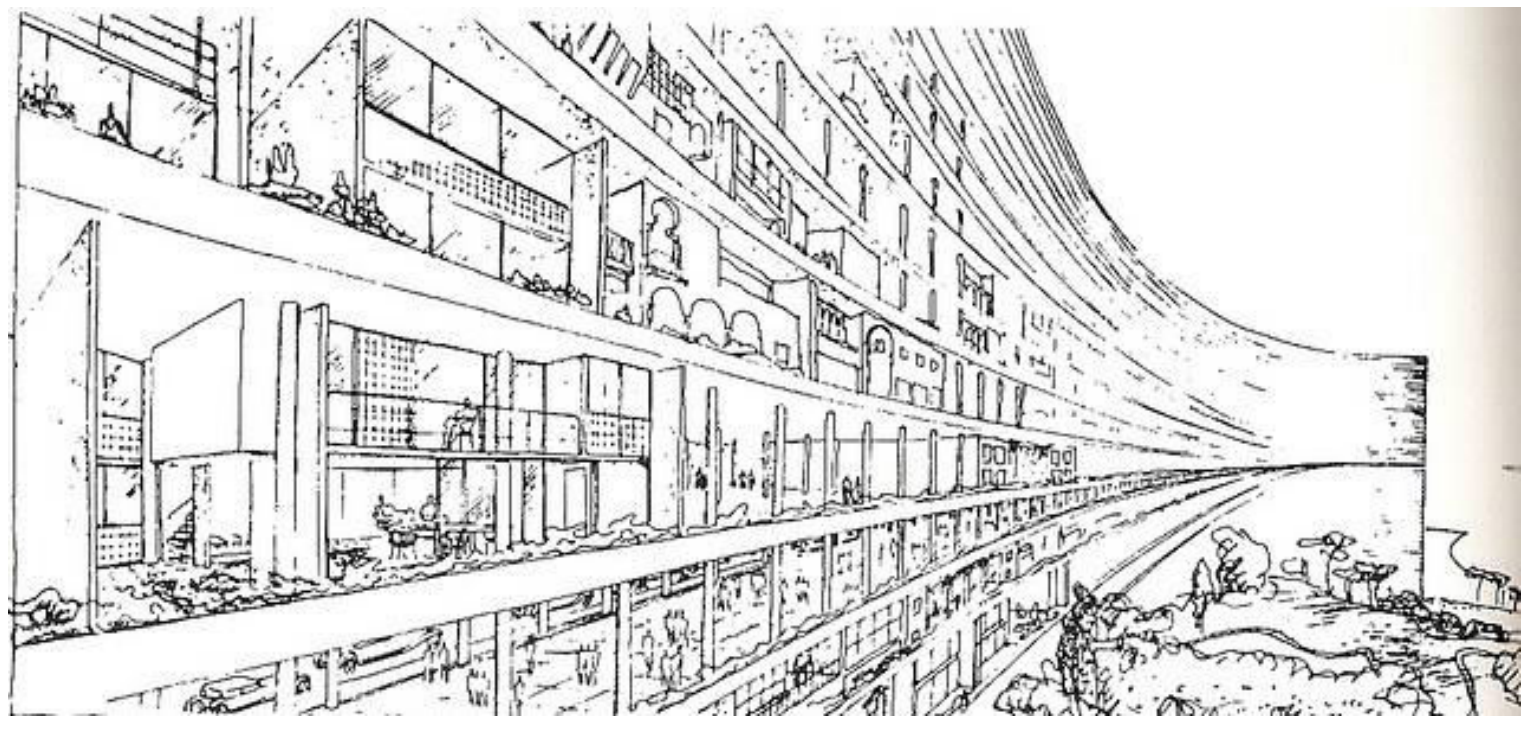

Сл. 6 Скица на Ле Корбизје на проектот во Алжир, (1933)

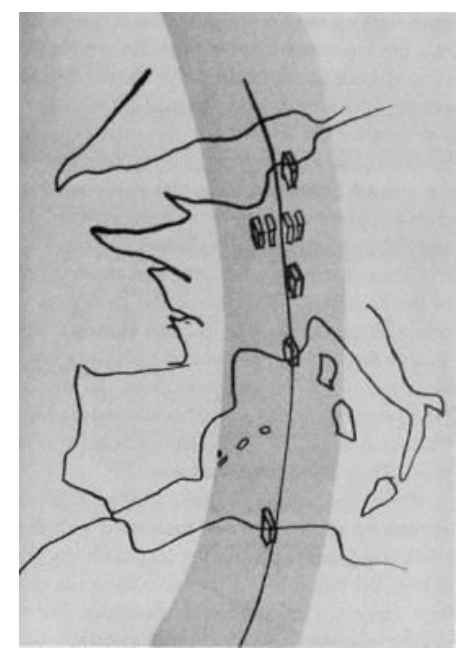

Сл. 7 Скица на Ле Корбизје - урбанистичка унификација на фрранцуските колонии

Линиската дистрибуција ќе доживее екстремни сценарија во шеесеттите и седумдесеттите години од дваесеттиот век, произлезени од новите технолошки перспективи како и критиките на старите индустриски и социо-културни модели на модерната. 
Марк Фостер Гејџ (Mark Foster Gage) го цитира Роберт А. Штерн (Robert A. Stern), кој пишува во истата година на слетувањето на Месечината: “...некои архитекти, возбудени од новите технолошки достигнувања кои ни се достапни, се обидуваат да најдат решенија кои се од голем обем и храбри во својот гест. Тие биле во искушение да замислат нови градови во огромен размер да ги заменат досегашните градови, нудејќи идеални решенија кои се ослонуваат на новите системи и технологии кои се сеуште во експериментална фаза." Овој цитат на архитектот Штерн, е критика на утопистичките предлози на своите современици, инспирирани од дотогаш неверојатниот шоу подвиг на американските астронаути со слетувањето на месечината. Во тој момент небото била границата и тој ентузијазам се пренел во сите сфери на животот на луѓето.

Од историски аспект, кон крајот на $60^{\text {те }}$ и почетокот на $70^{\text {те }}$, гледаме големи промени во теоријата на архитектурата и новите визионерски погледи за градот, се појавуваат амбициозни предлози за транформација на историскиот град со кои се поставуваат нови архитектонски парадигми. Се истражуваат негативните и позитивните аспекти на градот и нивното функционирање во едно нова доба на рапиден развој на технологии, се критикуваат општествените и политчките односи.

Должината е фрактор на кој што се базира архитектурата во овој период, со зголемениот број на превозни средства, изградбата на брзи сообраќајници, со што совладувањето на делечината станува се помал предизвик, а воедно и се зголемува предизвикот за наоѓање на просторни решенија и капацитети кои би ги

\footnotetext{
${ }^{1}$ Robert A.M. Stern, New Directions in American Architecture (New York: G.Braziller 1977), стр. 107.
} 
поддржале овие иновативни инфраструктури. Компактноста, подвижноста и механизацијата исто така претставуваат важни аспекти не само во дизајнот туку и во начинот на организација на умот, барајќи сложени компоненти кои перфектно ќе функционираат како целина. Фрагментите не функционираат едни без други, туку целината, "машината" е комплетна кога сѐ работи заедно. ${ }^{2}$

Од сите проекти, од концептуалните до територијалните хоризонти на просторот, можеби најјасен и чист во својата идеја е “Континуираниот град за еден милион жители" (Continuous City for One Million Human Beings), на Алан Боутвел (Alan Boutwell) и Мајкл Мичел (Michael Mitchell), во 1969 година, истата во која американските астронаути слетале на месечината. Проектот ја опфаќа целата должина на САД, поврзувајќи го градот Њу Јорк со Сан Франциско со едно континуирано испреплетување на архитектонски простор, инфраструктура и програма. Концептот се базира на подигнување на делови на градот од земјата, програмски поврзувајќи го сместувањето на намените, од авиони, шини, пешачка циркулација и паркинг за возила. Совладувајќи нови височини, основната тема заедничка за сите американски експерименти во овој период е базирана на инфраструктурата - и поврзувањето на хоризонталните издолжувања на системите на автопатите, со прагматичните грижи за засолниште и пешачкиот живот. Ботвел и Мичел за својот проект пишуваат: “...основно е планирањето на национална скала. Да се остават регионалните администратори да ја предвидуваат иднината е катастрофално". ${ }^{3}$

\footnotetext{
${ }^{2}$ Foster Gage, Mark, Along Utopian Lines: American Architecture in the Age of Apollo, Volume 25, cтр. 64-69 2010

${ }^{3}$ Boutwell Alan и Mitchell Michael, "Planning on a National Scale", Domus 1, 1969, стр. 2-5
} 


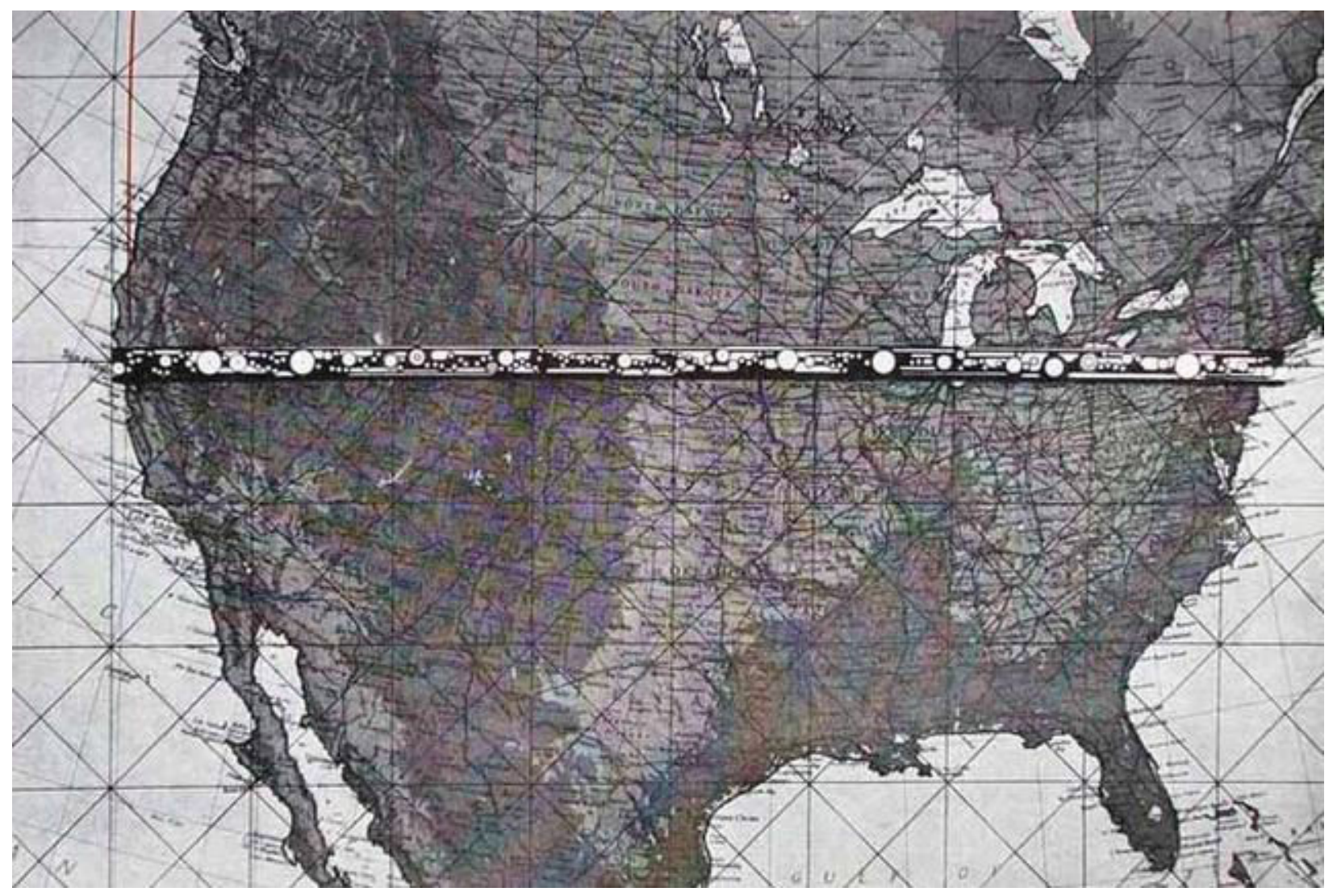

Сл. 8 Континуиран град за еден милион жители, Алан Боутвел и Мајк Мичел, (1969)

Сличен во намерата да приспособи исто така драматичен ревидиран концепт на архитектонско растојание, тоа е “Lower Manhatten Expressway” на Пол Рудолфр (Paul Rudolph), во 1967 година. Во овој проект, Рудолф предлага целосна интеграција на брзиот транспортен сообраќаен систем со линеарен, но прагматичен систем на резиденцијални, комерцијални и други сродни намени. Специфичниот проблем кој го дефинирал Рудолф и Форд Фондацијата, спонзор на овој спекулативен проект, бил да се помират постоечките урбани енвироменти со тие создадени со новите инфраструктурни рути и конкретно, со Долен Менхетен. Решението на Рудолф било во пресекот на линеарните инфраструктури во една густа, но тектонски рационализирана агрегација на 
префрабрикуван бетон. Густината на овој репетитивен линеарен систем бил модулиран со прилагодување на релативните височини на програмските површини - и со тоа овозможувајќи интеграција на потребите на човекот на големи дистанци, сепак овозможувајќи механизам кој би можел да му одговори на физичкиот контекст од околното урбано ткиво каде што програмската линија ќе поминува. Просторот за живеење кој Рудолф го предлага е доста радикален, но пред се тој е реален - илустрирајќи прагматичен пристап. Иако никогаш не бил изграден, овој проект имал големо влијание на дизајн идеите на своите современици како и во иднина.

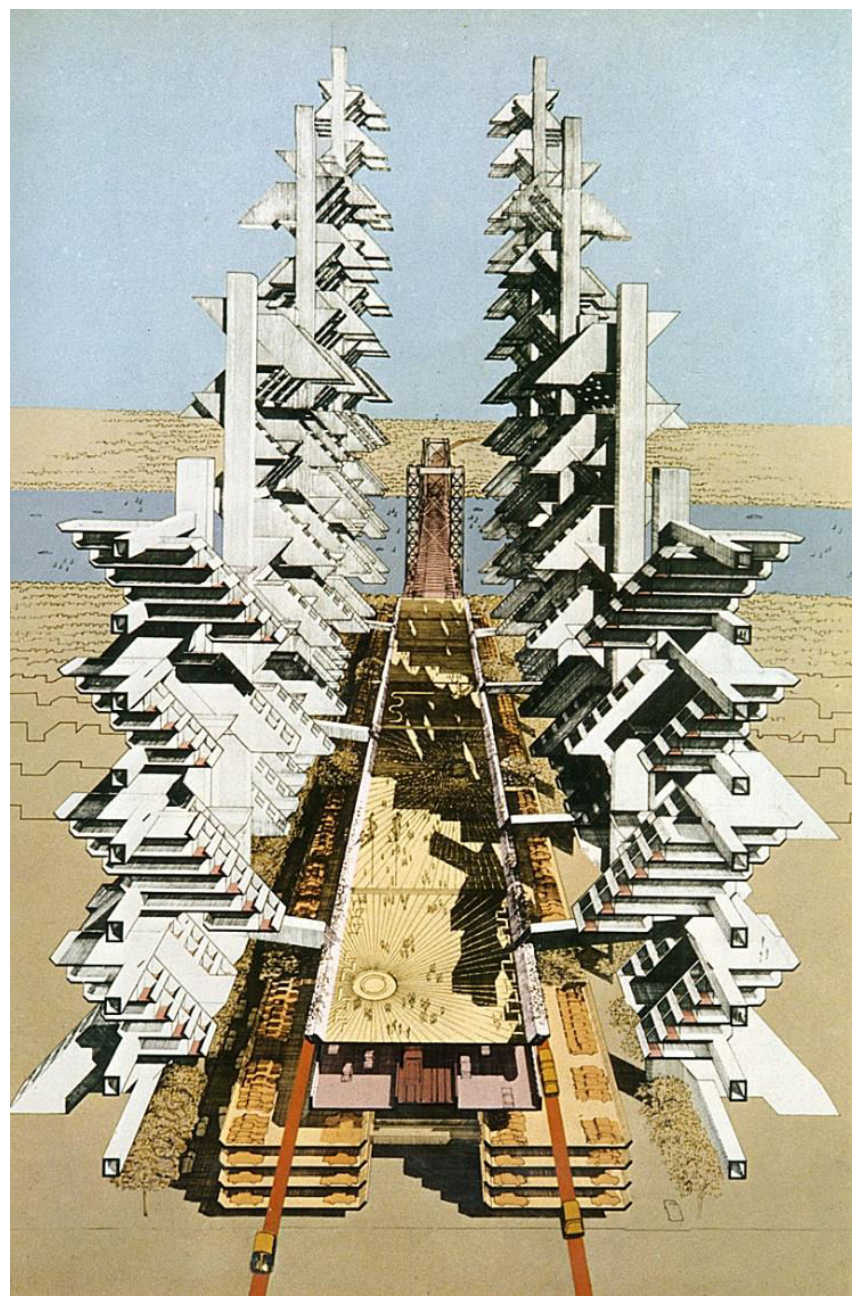

Сл. 9 Пол Рудолф - The Lower Manhattan Expressway (1976) 
Последователно, откако го споменавме Пол Рудолф, неизбежно е да го споменеме трудот на професорот Георги Константиновски, на студиите на Универзитетот на Јеил под менторство на Рудолфф во 1965 година, кој се надоврзува на сензибилитетот на мега структури на таа школа во тој период.

\section{Архитектонско-урбанистичкото решение на Харлем, Њу Јорк на Георги}

Константиновски, според архитектот Винсен Сколи (Vincent Scully), претставувало решение работено со голема суптилност и со својот експресионистички израз може да се споредува со експресионизмот на Менделсон.

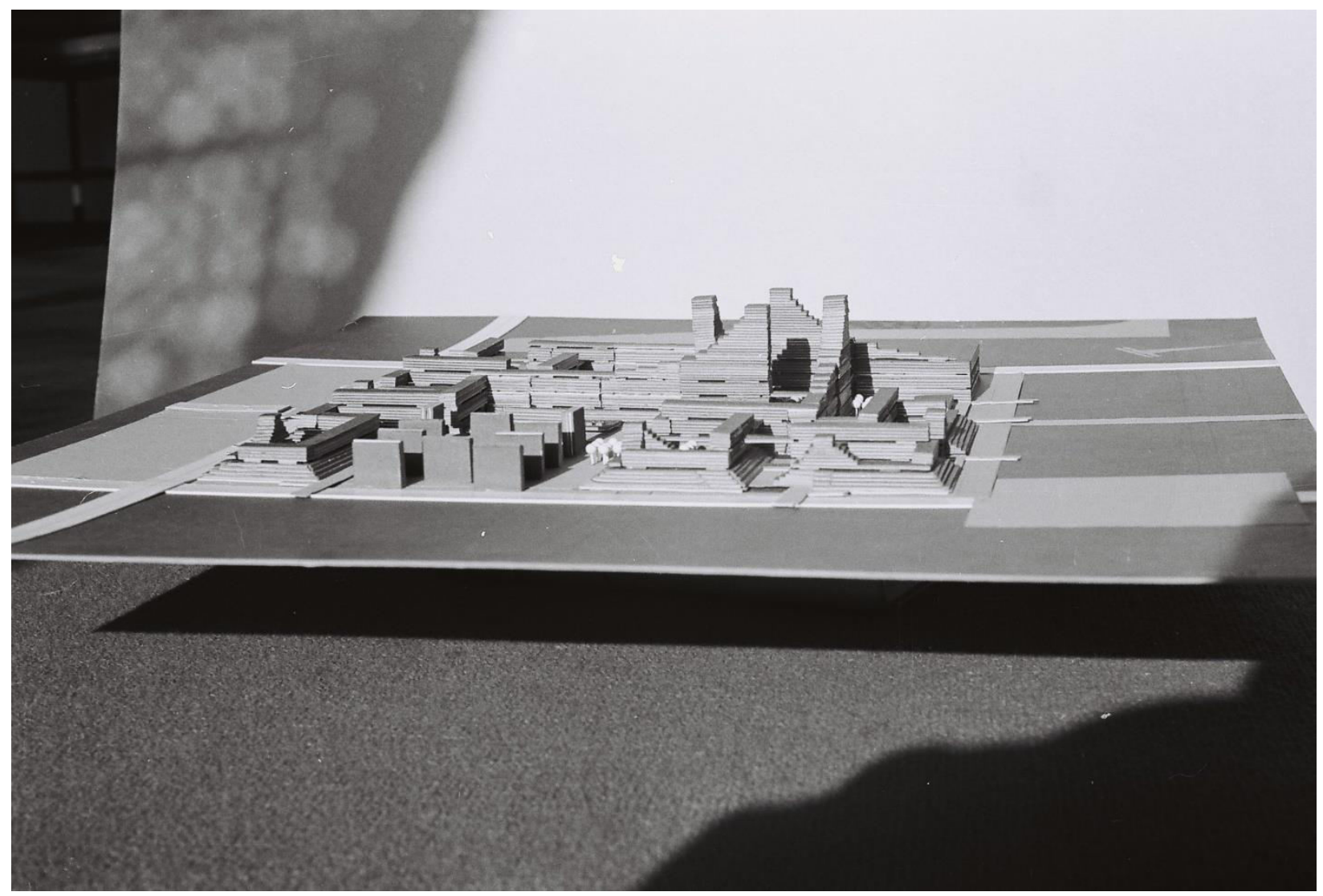




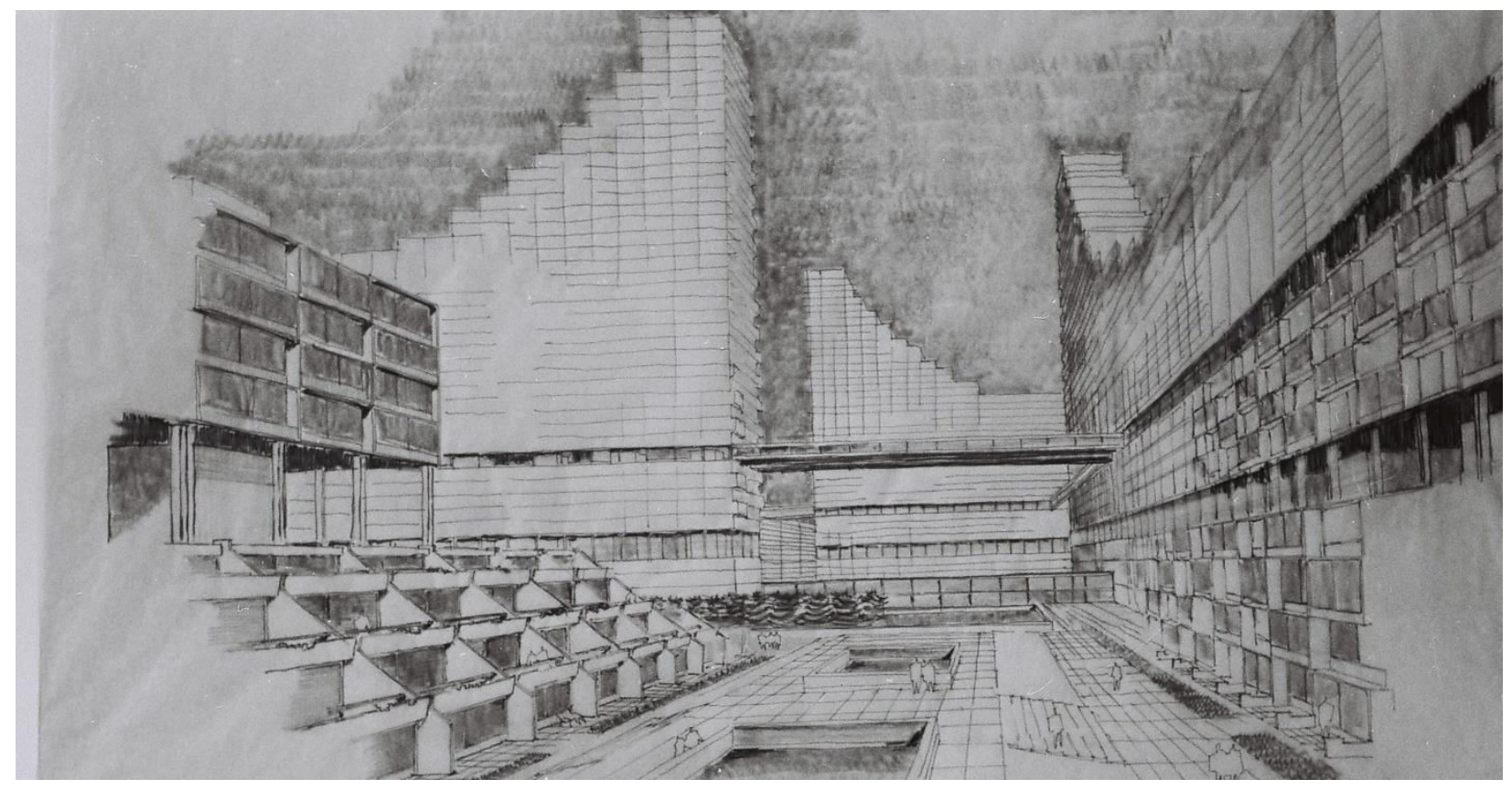

Сл. 11 Скица - перспектива, поглед кон централниот дел на решението

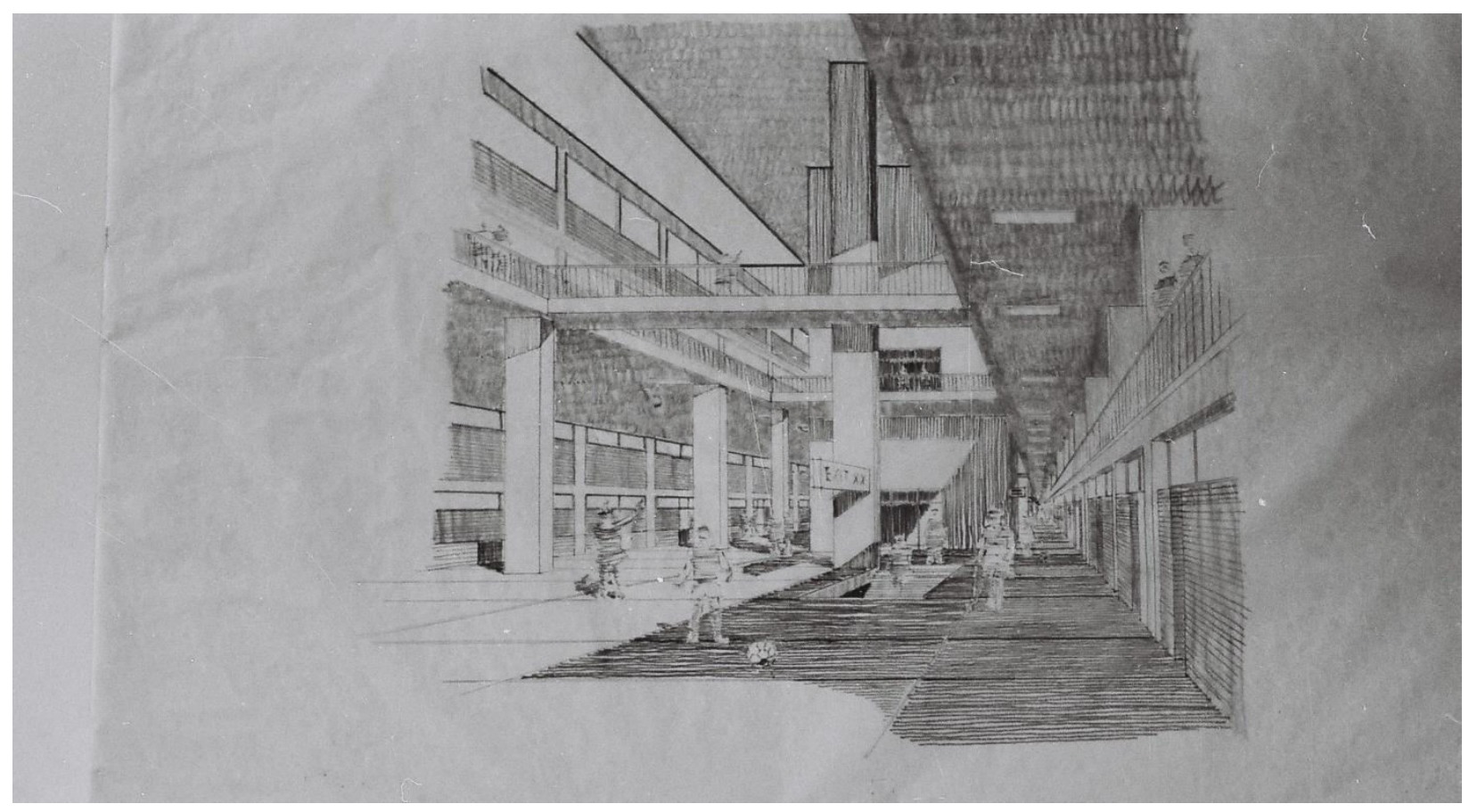

Сл. 12 Скција - перспектива, поглед низ внатрешните пешачки улица 
Во истражувачкиот проект на DOGMA на Пјер Виторио Аурели и Мартино Татара наречен “Stop City” се истражува фрормата на современиот град преку поставување на градот на самата линија на границата на урбанизираниот и празниот простор. Предвидениот град претставува архипелаг од острови со голема густина. Исто како и во проектот Stop City, овој проект се воздржува од архитектура; ова е модел во кој што нема архитектура како што е традиционално планирана, туку само како проба за архитектонски да се врами градот. Архитектура без атрибути, ослободена од слика, од стил, од облигацијата за екстравагантност, од бескорисното создавање на нови форми. Тоа е архитектура ослободена од самата себеси.

“No-stop City” на Archizoom го редуцирал капиталистичкиот град во едно континуирано поле кое треба да се втопи во изградената структура на градот во неговите организациони елементи - столбови, лифтови, зидови итн. Разликите како внатре-надвор, производство и потрошувачка, живеење и работење, пејсаж и град, се вклопени во една опремена површина која што може да се шири во сите насоки во рамките на претпоставена мрежа која што претставува најгенеричкиот ред што постои. No-stop City е хипер-реалистичен проект - градот е тоа што прави. ${ }^{4}$ Градот е континуирана околина создадена од репетитивни состојби на светлина, комуникации, механички транспорт и сите социјални конекции материјални и нематеријални кои се потребни за градот да функционира и да се репродуцира. No-stop City ги формализира условите кои што прават еден град. Тој

\footnotetext{
${ }^{4}$ Aureli, Pier Vittorio и Tattara Martino, Stop City, (http://ebookbrowse.com/stop-city-dogma-pdf-d45768517), 2007
} 
не е ни предлог за нов утопистички град, ниту трансформација на стариот град, туку еден концептуален рентген на постоечката капиталистичка метропола. Ова е важно за да ги сфратиме односите и процесите во градот на едно поинакво ниво на перцепција, без дефокусирање на погледот на градот и неговите составни делови, можеби повеќе функционалистички пристап од аспект на процесите што го сочинуваат истиот. Односот што го имаат жителите со градот, нивното место на домување во однос на местото на работа и сите останати сфрери на живеењето во урбана средина, различните активности кои им се достапни, се еднакви со активностите што ги имале работниците во фабрика. Градот е една современа фабрика во која главниот акцент е поставен на фракторот на производство, а граѓаните новата работна класа. Наспроти ова стои екологијата, одржливоста и хуманите услови за живеење, кои во поголема или помала мера го сочинуваат урбаниот простор.

Концептот на граница; во проектот "Stop City" на Догма се презентира и се разработува проблемот на градската фрорма не само од морфолошки аспект, туку исто така во поширока смисла на фрормален и политички концепт на форма, концептот на граница. Низ продукцијата на архитектонскиот проект се стекнуваат две нивоа на значење: првата референца е на физичката аспект на границата; главно поставувајќи ограничувања и стопирање на процеси на бесконечниот раст на градот. И второ, во концептуален термин, се однесува на идејата дека архитектурата треба да и го сврти грбот на драмата на новитетот и да ги дефинира со концептуална јасност и формален пример прототипските форми на густина. 
Мноштвото на значења на концептот на граница своите корени ги наоѓа од амбиваленцијата на самиот акт на поставување на граница. Ако поставувањето на граница претставува почетокот на секоја човекова населба, исто така претставува почетокот на некоја фрорма на јурисдикција. Обележувајќи го земјиштето, трасирањето на границата, не се само исконски форми на поставување на населба од страна на луѓето, формации преку кои се прикажува моќ кои се основани на нови просторни поделби, нови простори за домување и нови просторни распореди на земјиштето.

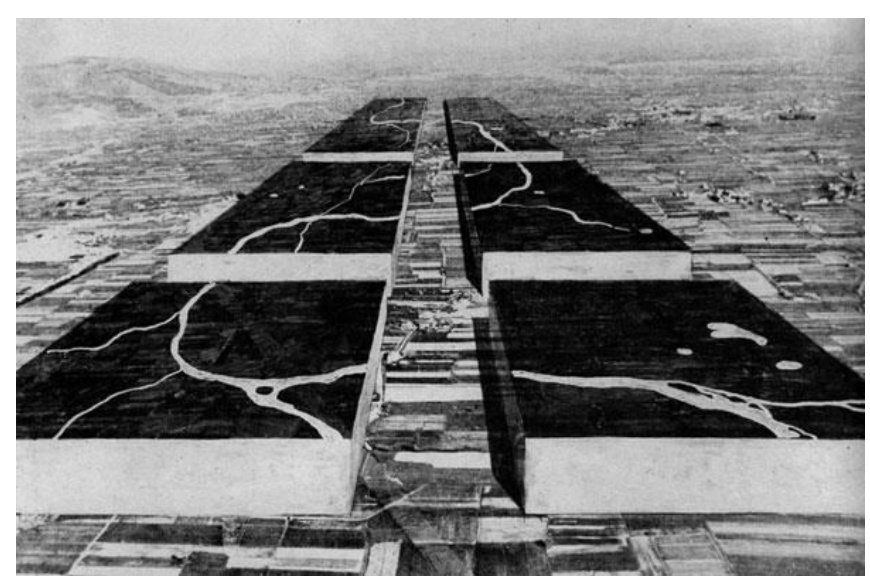

Сл. 13 "No Stop City" - Archizoom (1970)

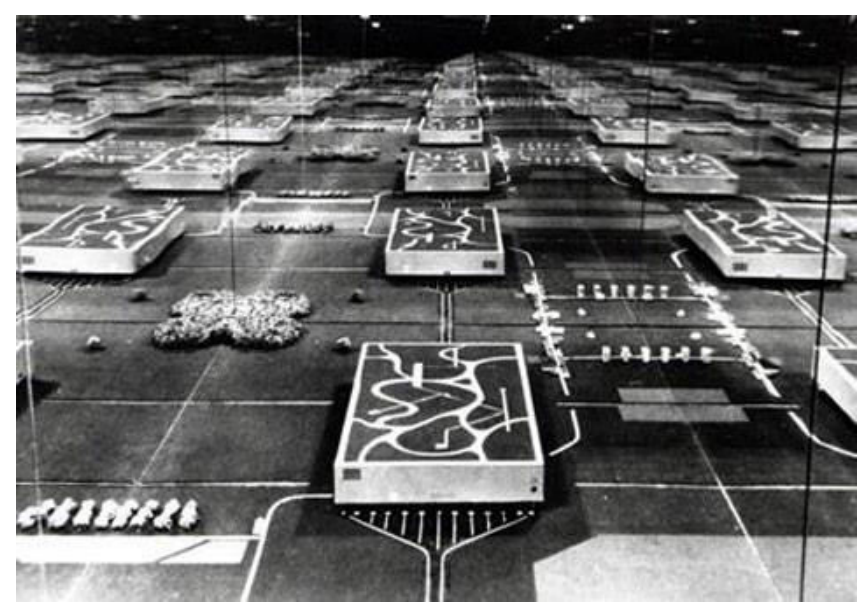

Сл. 14 "No Stop City" - Archizoom (1970) 


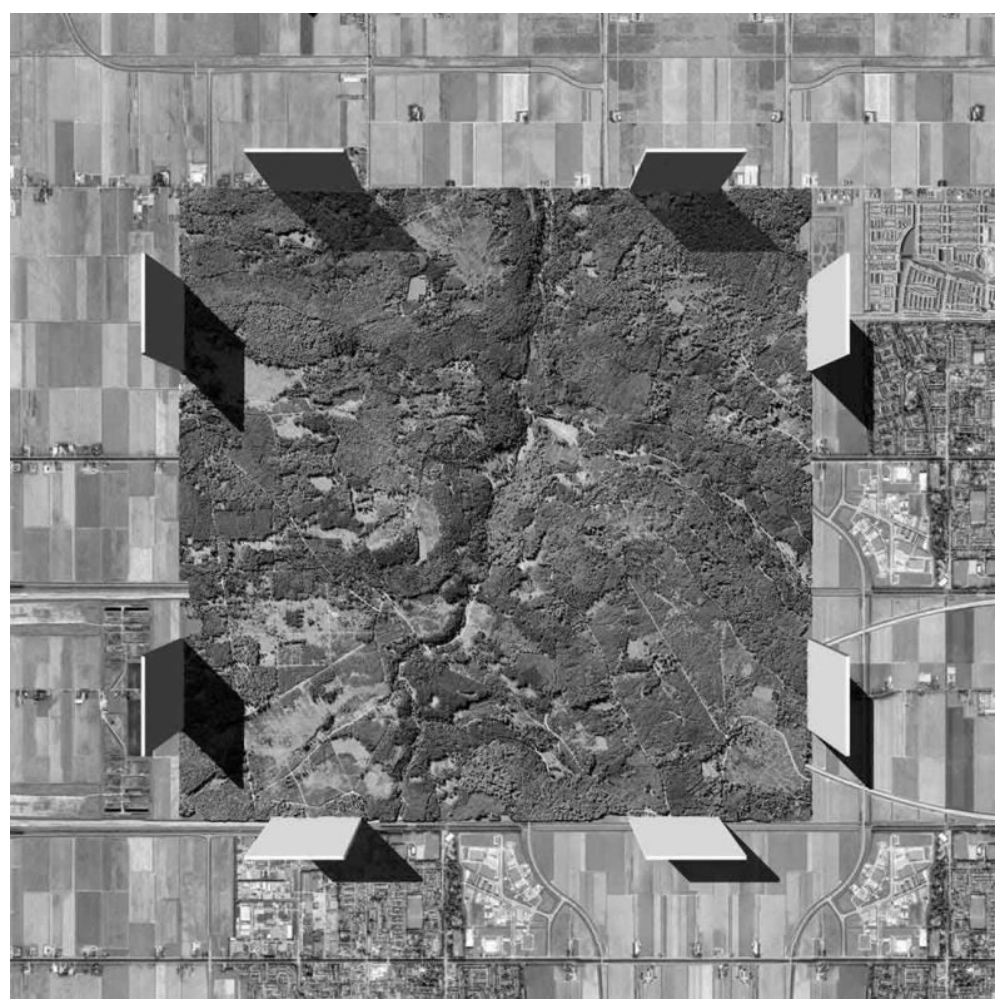

Cл. 15 "Stop City" - Dogma (2007)

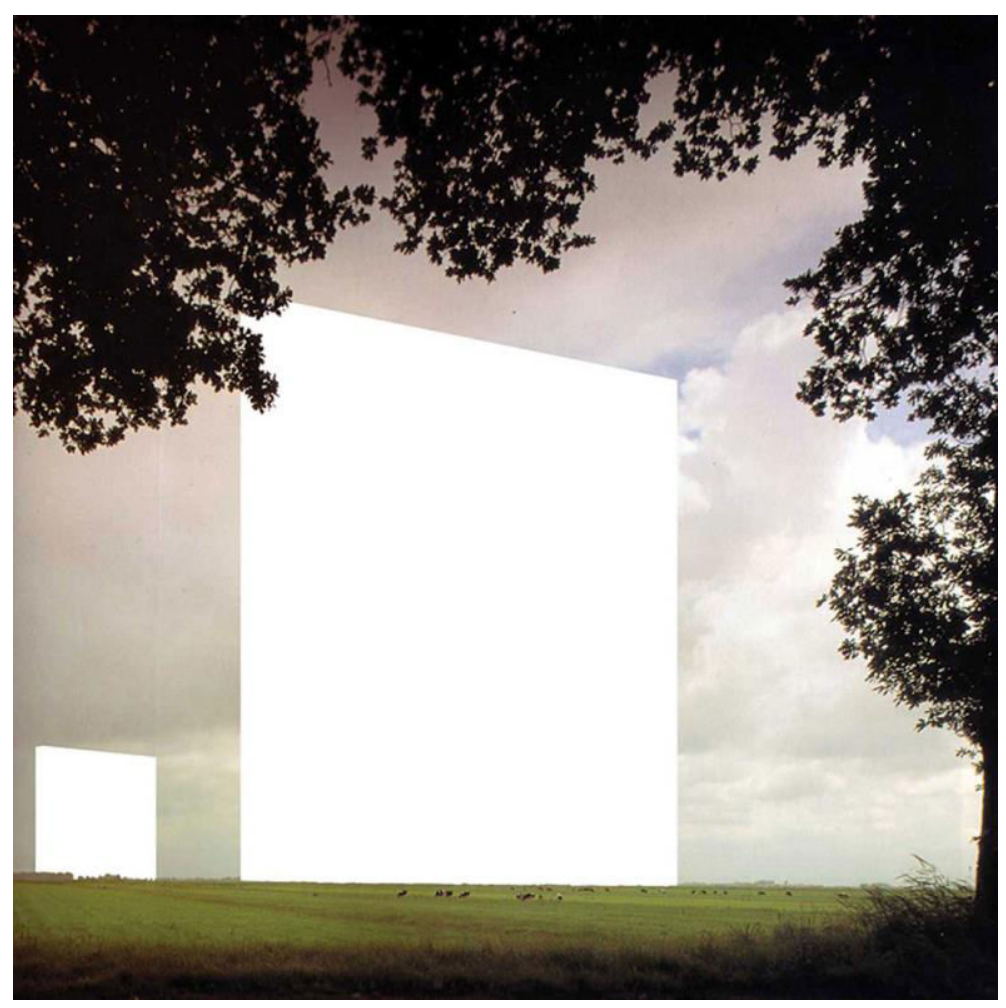

Cл. 16 "Stop City" - Dogma (2007) 


\section{3. Линии на издвојување}

Својството на линеарна дистрибуција е поврзување долж протегање на линијата, но истовремено во другиот правец претставува граница или издвојување на домените. Ако серија проекти укажуваат на линиската дистрибуција како аспект на поврзување, токму линијата како прекин или граница ќе предизвика една спротивна концептуализација и пракса на нејзина примена.

Најголемата човечка творба е линиската фрортификација долга 6325 километри, Големиот кинески sид. Големиот кинески sид (Wanli Changcheng, буквално “10000Li долг sид”), е монументална фортификација изградена од 3 век п.н.е. до 17 век, за да ги заштити различните династии од номадските племиња кои доаѓале од подрачјето на денешна Монголија и Манџурија. Во најголемиот дел ја означува границата помеѓу северна Кина и внатрешна Монголија.

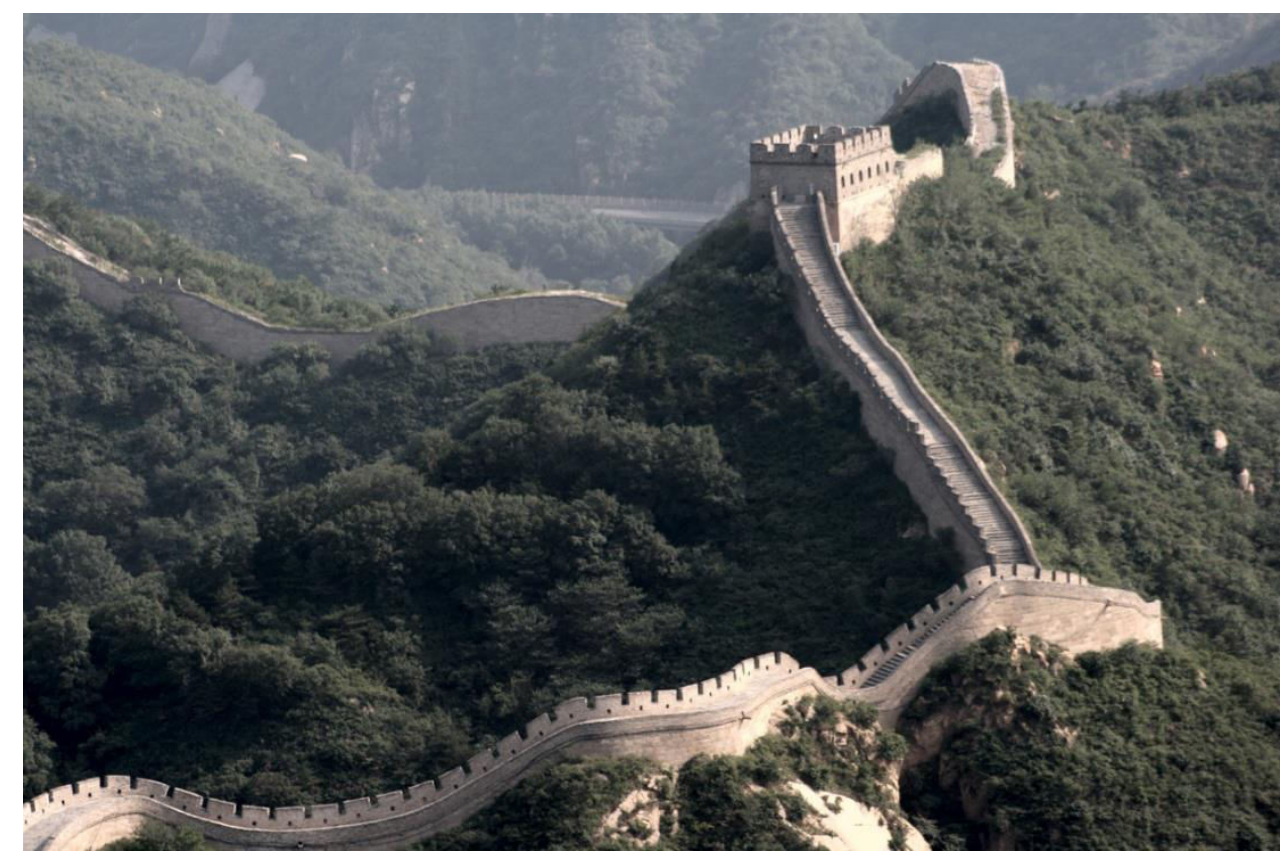

Сл. 17 Големиот кинески sud, (3 век п.н.е. - 17 век) 
Во сосема друг географски и политички контекст, но со слична протективна и делимитирачка функција е поставен Берлинскиот sид. Зидот беше една бариера изградена од Германската Демократска Република (GDR, Источна Германија), почнувајќи од 13 август 1961 година, сосема го отсече Западен Берлин од Источен Берлин и околната територија на Источна Германија. Бариерата се состоеше од кули со чувари долж висок, бетонски sид, кој што ограничуваше широка површина наречена “лента на смртта”, која што се состоеше од ровови, бодликава жица, минско поле и војници со кучиња. Источна Германија тврдеше дека го изградила sидот за да го заштити населението од профашистичките елементи кои конспирираат за да го спречат создавањето на една социјалистичка држава од Источна Германија. Во пракса, зидот служел за да се спречи масивното мигрирање на населението од Источна во Западна Германија.

Берлинскиот sид официјално се именуваше како "Anti-Fascist Protection Rampart", од официјалните власти. Западно Берлинските авторитети често го нарекуваа “Sид на срамот”, термин кој потекнува од канцеларот Вили Брант, реферирајќи на ограничувањето на слободното движење. Берлинскиот sид, иако само сегмент од границата помеѓу источниот и западниот блок, потполно ја симболизираше издвоеноста и поделбата на Европа во втората половина на дваесеттиот век. 


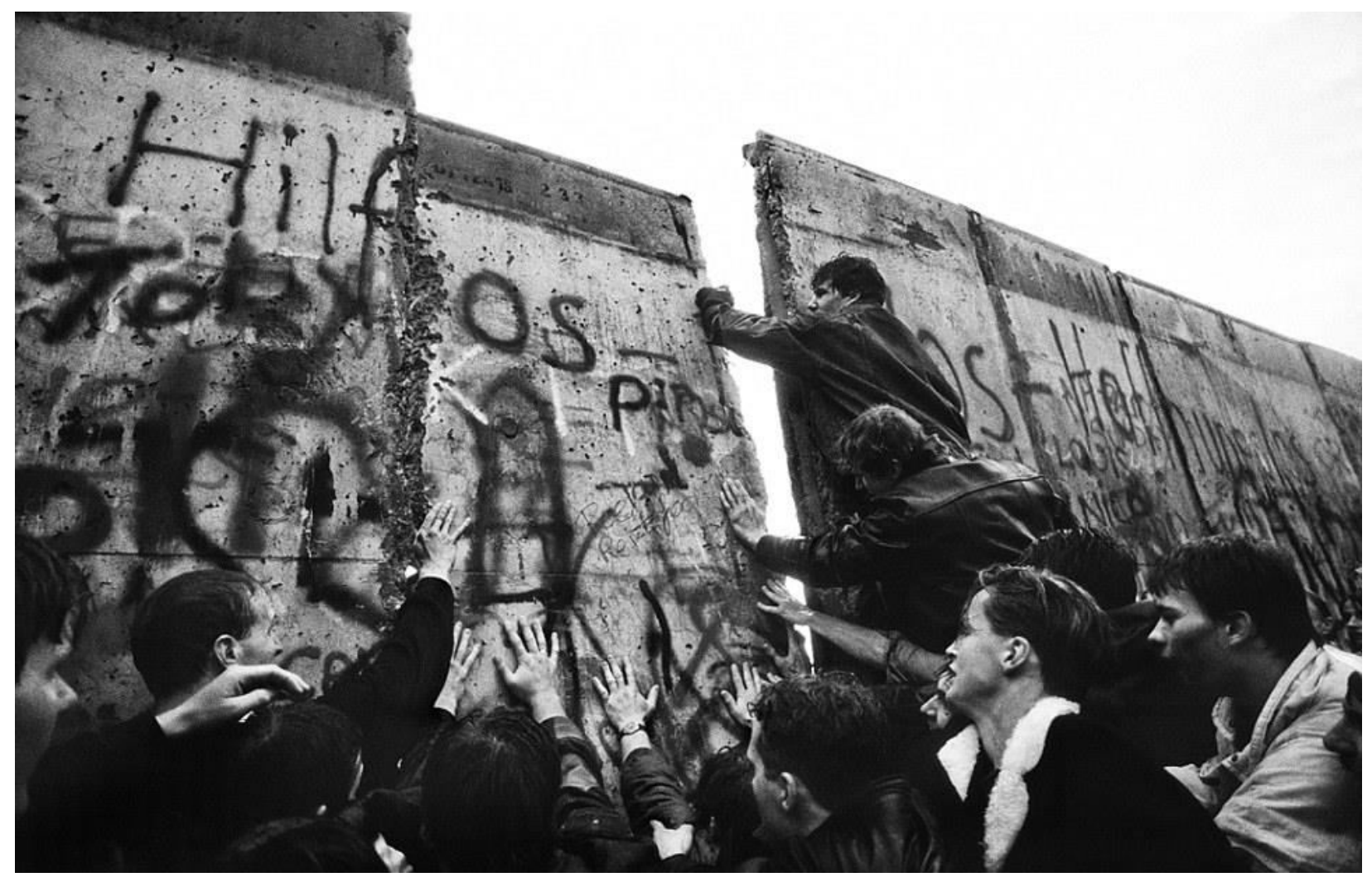

Сл. 18 Рушење на Берлинскиот sид, (1990)

Вим Вендерс (Wim Wenders), во филмот “Небо над Берлин” (Der Himmel Uber Berlin), најсугестивно ја изрази метафизиката на поделениот град, поставувајќи го во контекст на дефинирањето на себе во однос на другите. Како што возачот на такси ќe го искаже тоа: “Дали сеуште има граници? Повеќе од секогаш! Секоја улица ги има своите граници. Помеѓу секоја парцела, постои трака на ничија земја маскирана како ров. Кој што ќе се осмели, ќе падне во стапица од мини или ќе го исечат ласерски зраци. The trout are really torpedoes. Секој сопственик на дом го закачува своето име на вратата, како грб и го проучува утринскиот весник како да е светски лидер. Германија се распадна на исто толку мали 
држави колку што има жители. И овие мали држави се мобилни. Секој си ја носи државата со себе и бара наплата ако некој сака да влезе. Мува фратена во килибар или кожнено шише. Толку од границата. Но за да влезе некој во државата на друаиот потребна е лозинка. Германската душа на денешницата може да биде освоена и владеена само од оној кој што ќе дојде со лозинка. За среќа, моментално не е никој во таа позиција. И...сите мигрираат, и го вее своето сопствено знаме на сите страни. Нивните деца веќе ги тресат тропалките и го влечат нивниот смет околу нив во кругови". ${ }^{5}$
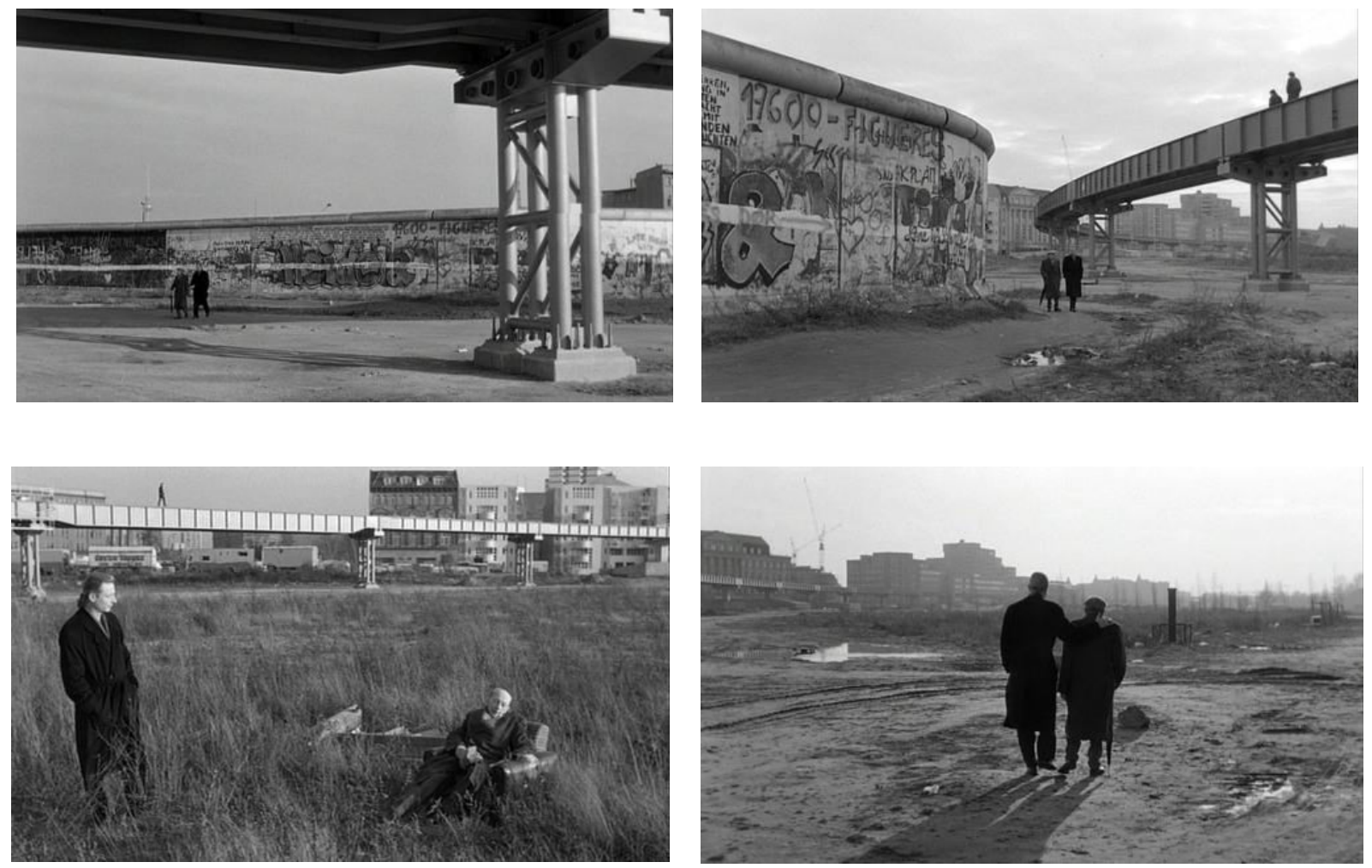

Сл. 19 Сцени од филмот "Небо над Берлин"на Вим Вендерс (1987)

\footnotetext{
${ }^{5}$ Wenders, Wim, "Der Himmel Uber Barlin", 1987
} 
Проектот на Елија Зенгелис (Elia Zenghelis) и Рем Колхас (Rem Koolhaas), “Exodus: The Volontary Prisoners of Architecture” (1972), се темели на механизмот на исклучување предизвикан од инцизија на градската планиметрија. Колхас напиша: “Еднаш, градот беше поделен на два дела. Едниот дел беше Добрата Половина, другиот Лошата половина. Жителите на Лошата Половина започнале да пребегнуваат во добрата половина на поделениот град, брзо полнејќи го во еден урбан егзодус. Ако оваа ситуација би продолжела понатаму, популацијата на Добрата Половина би се удвоила, додека Лошата Половина би се претворила во град на духови. После сите неуспешни обиди за да се спречи оваа миграција, авторитетите на лошата половина започнале со очајни мерки градејќи sид околу добрата половина, правејќи ја целосно недостапна.

Suдот беше ремек-дело.

Suдот претставуал не повеќе од една патетична бодликава жица нагло оставена на замислената линија од границата, но психолошките и симболичките ефекти биле бескрајно помоќни од фризичкиот изглед. Добрата Половина, сега sиркајќи од позади една забранета пречка, била уште понеодолива. Тие што биле заробени, останати во Лошата Половина, станале опседнати со залудни планови за бегство. Безнадежноста царуваше на погрешната страна на sидот. Како што толку често тоа се случувало во историјата на човештвото, архитектурата беше виновен инструмент на oчajom" ${ }^{6}$

\footnotetext{
${ }^{6}$ Koolhaas, Rem, Exodus: The Voluntary Prisoners of Architecture, 1972
} 

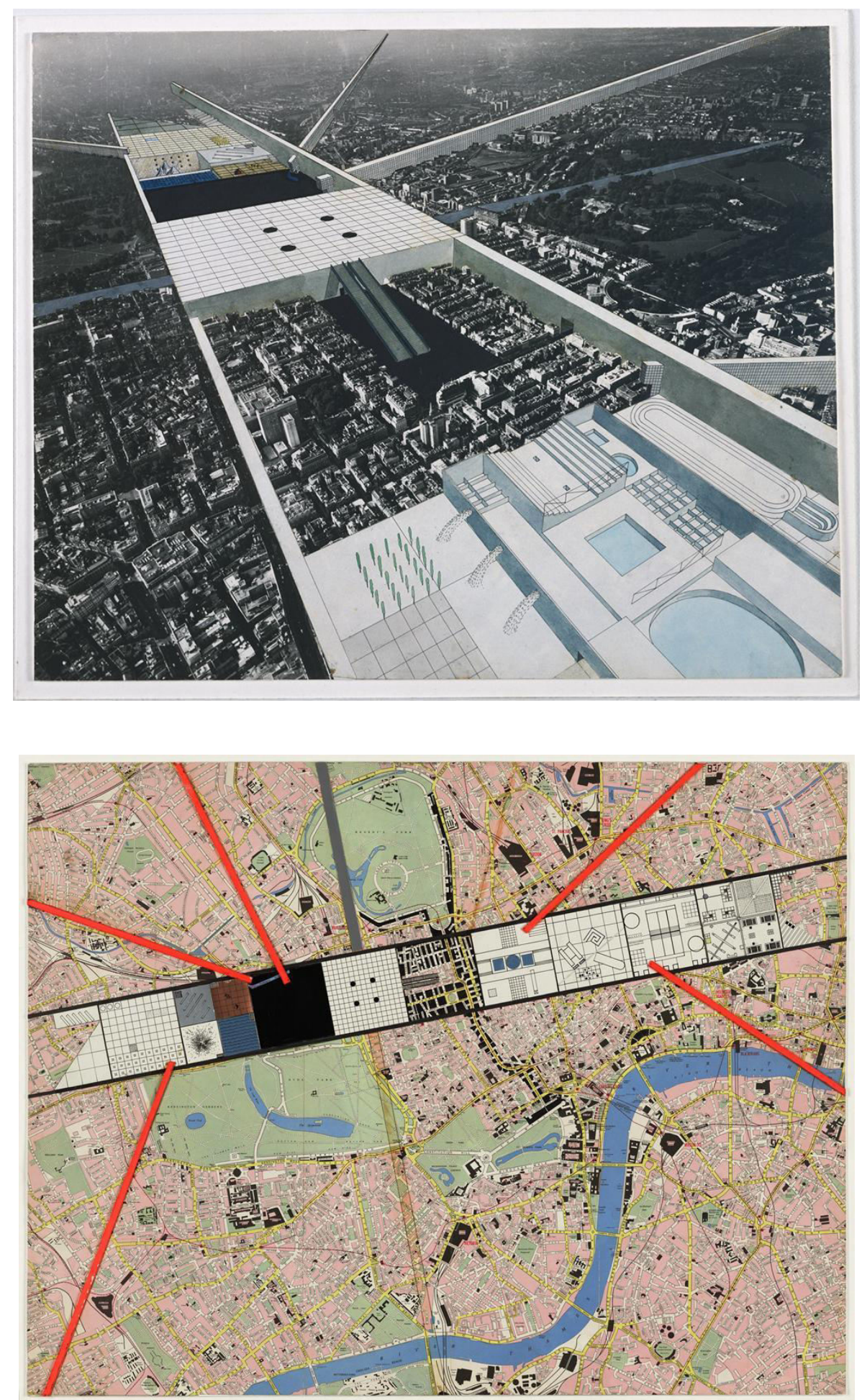

Сл. 20 Просторен приказ и ситуација, "Еходиs" Рем Колхас и Елија Зенгелис (1972) 
Несомнено линиските конфигурации се темелат на еден од архетипските схеми на перцепција и организација на просторот. Нејзините геометриски и просторни карактеристики последователно даваат амбивалентно значење, една линија може да поврзе, но и да издвои. Во сукцесивните примери ги следевме својствата на линиската организација како орудие на поврзување, физичко-просторно интегрирање, како духовно, симболички, но и производен, материјален процес. Основа за надминување на историските урбани фрормации, но и механизам за технолошки и социјално-културни трансформации на постојното. Начин на издвојување, на милитаристичко, политичко конфронтирање, но и место на преиспитување на постојното. Токму преку ваквите амбивалентни својства, инцизија, како пресек кој издвојува, но и спојува, ја прави оваа постапка како продуктивна тактика во современите противречни урбани ситуации. 


\section{2. Скопје - од радијален кон линиски град}

Фокусирајќи се на предметот на истражувањето, градот Скопје и неговата актуелна ситуација, најпрво треба да ги објасниме историските процеси кои го дефинирале Скопје каков што е денес. Скопје влегува во категоријата на балкански традиционален град. Во рамките на докторскиот труд на професорот Минас Бакалчев, преку препознавање на три принципиелни слоја, дефинира три периода на архитектонскиот развој на Скопје и негова трансформација во $X \mathrm{X}^{\circ \top}$ век. 1. град - мозаик на субкултури, традиционален балкански град

2. унитарен модел, реконструкција кон европски тип

3. унитарен модел, реконструкција кон интернационален тип Преку овие три слоја можеме да ги дефинираме главните карактеристики кои го трансформираат градот. Левиот брег на реката Вардар е историското место на формирање на просторната организација на традиционалниот балкански град. Тој по својата морфологија е мозаичен, град - мозаик, град кој својот идентитет го добива преку локалните специфичности.

Во своето истражуување, Бакалчев препознава два типа на постапки на внатрешна архитектонска трансформација на традиционалниот балкански град, постапката на суперпозиција и јукстапозиција на новите елементи во традиционалниот контекст. ${ }^{7}$

\footnotetext{
${ }^{7}$ Бакалчев, Минас, Домување како урбан фрагмент, необјавена докторска дисертација, стр. 43, 2004
} 

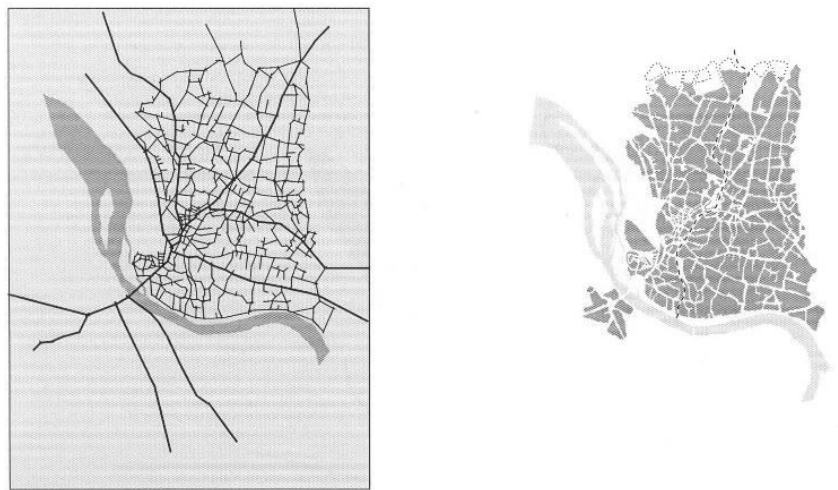

Сл. 21 Лево: Аксијална мапа на Скопје пред воведувањето на железницата (пред 1873) Десно: Морфолошка анализа блоковска диференцијација
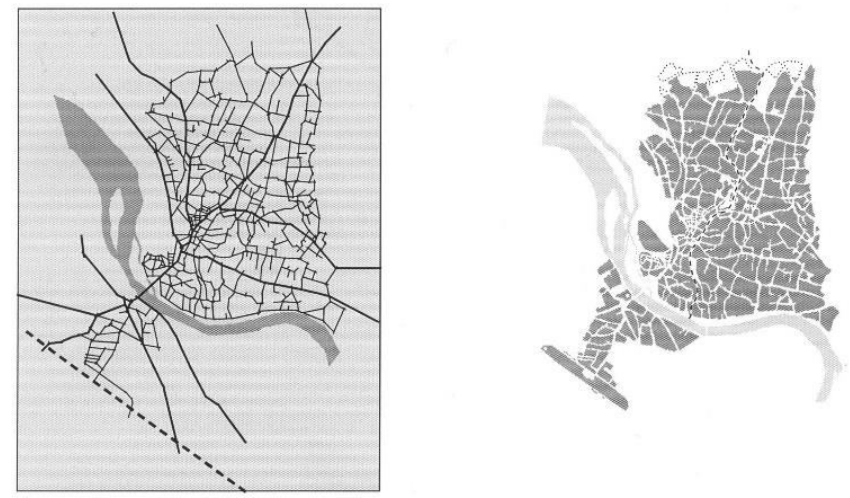

Сл. 22 Лево: Аксијална мапа на Скопје со воведување на железницата (1873) Десно: Морфолошка анализа - блоковска диреренцијација
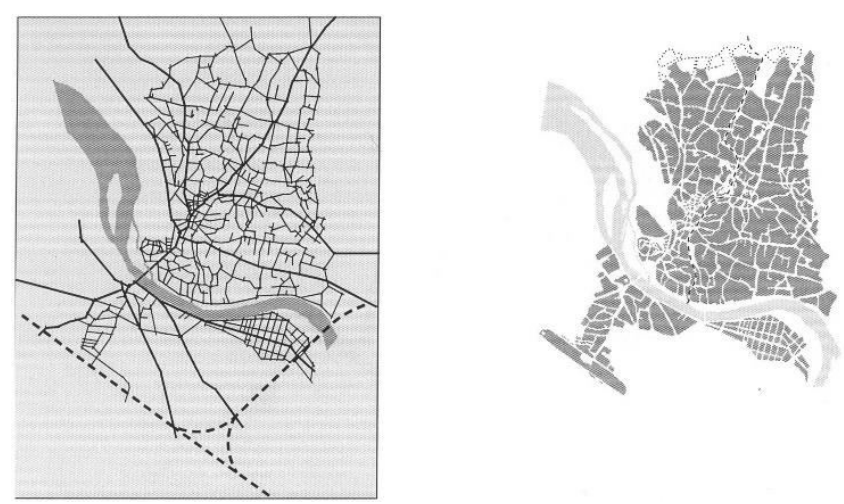

Сл. 23 Лево: Аксијална мапа на Скопје со воведување на новата железничка линија (1888) Десно: Морфолошка анализа - блоковска диференцијација 
Во следната точка на истражувањето, прикажан е планот на Димитрија т. Леко (1914), кој нуди една нова теоретска основа на принципите на уметничко обликување на градовите, ирегуларна основа на планот и фрагментирањето на градскиот простор. На ирегуларните улични планови се суперпонира кружниот прстен (рингот), како главен структурален елемент на планот, обединувајќи го централното градско подрачје од левиот и десниот брег на градот. Може да констатираме дека во почетокот на XX век се појавува кружниот систем и градот добива една радијално-концентрична морфологија.
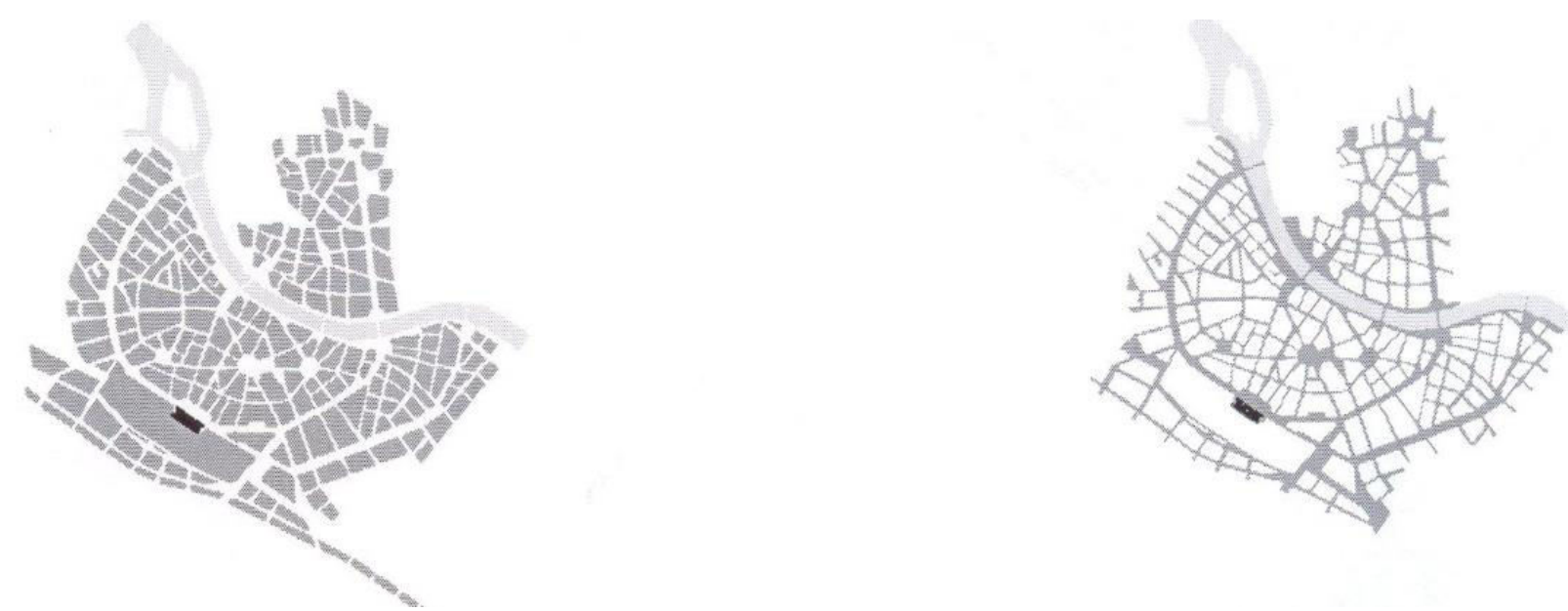

Сл. 24 Морфолошка анализа на регулациониот план на Д. Леко (1914) - блоковска и улична текстура 
На овој регулационен план се надоврзува планот на Ј. Михајловиќ (1928), кој ја продолжува морфолошката и програмската матрица на планот на Д.Т.Леко, редефринирајќи ја ирегуларната основа, во поизразен фрормален, геометриски образец.
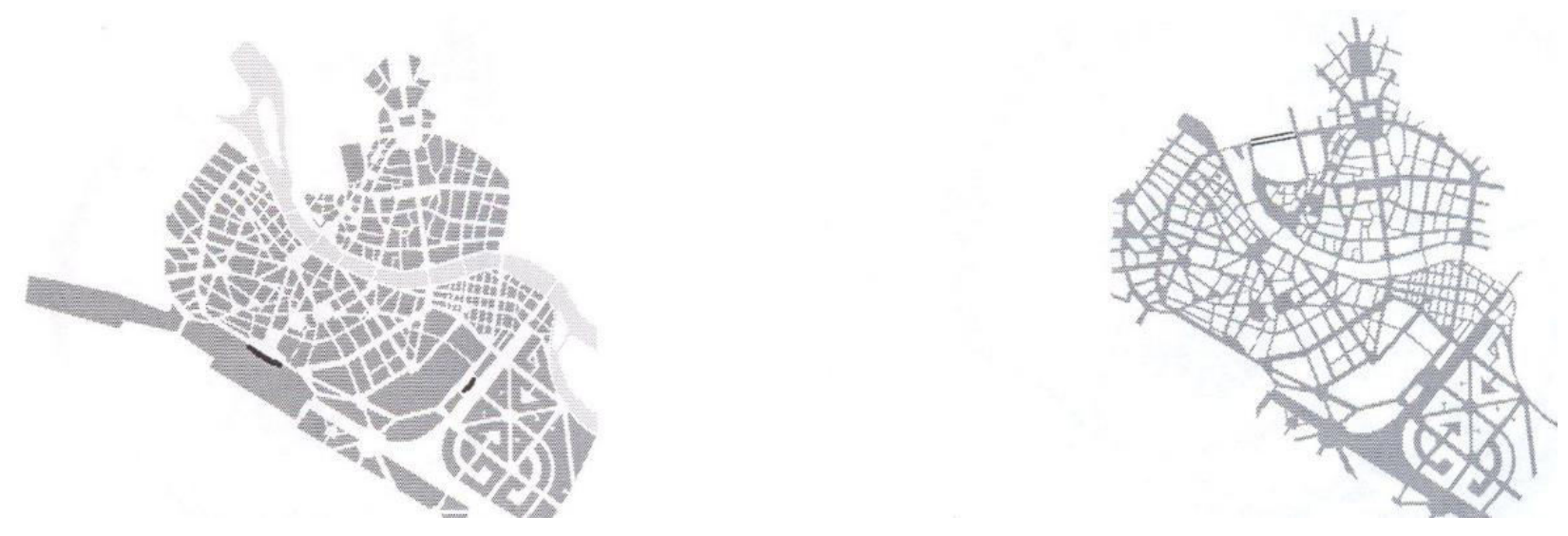

Сл. 25 Морфолошка анализа на планот на Ј. Михајловиќ (1924) - блоковска и улична текстура

Во втората половина на XX век, со изработката на генерален регулационен план на Скопје на група експерти од Чехословачка, на чело со архитектот Лудек Кубеш (1948), планирана е една прогресивна екстензија на градот, која означува премин од централен, радијален тип, кон линеарен град. Се промовира функционалистичкиот град, изведен од доктрината на CIAM, Атинската повелба (CIAM 1933), и методите на поделба на градот на четири зони и функции: домување, рекреација, работа и транспорт. Бакалчев десринира три нивоа во идеологијата на планот: 
1. Конвергирање на градот и државата - градот го репрезентира државниот идентитет

2. Преформирање на градот според актуелната индустриска парадигма машински град

3. Дефинирање на компонентите на градот во единствен унитарен систем Површината на градот е дефинирана во однос на преферираната густина од 150200 ж/ха како еден функционален дијаграм составен од диференцијални функционални категории: административни/трговски центар, станбена зона, културно/историска зона, научно/индустриска зона, зона на слободни површини. Уличниот модел е тој што ја десринира линиската структура на градот. Транспортната матрица е дефринирана со неколку принципи; главна комуникациска линија, исток - запад; врска помеѓу железничките станици - главна патничка станица и станица север за тешка индустрија; кружен собирач, кој не дозволува да влезе теретниот транзитен сообраќај во центарот на градот. Станбената зона е дефинирана со станбени периметарски блокови и слободно стоечки блокови кои со зелениот простор околу нив прават една целина. ${ }^{8}$ Овој план, во индина ќе го определи тој линеарен раст на градот во правец исток - запад и ќе ги дефринира функционалните зони кои се тема на обработка и истражување на оваа магистерска работа. Планот на Л.Кубеш го земаме за рефрерентен, поради тоа што во него за прв пат се појавуваат елементите кои ќе го детерминираат понатамошниот линеарен раст на градот, а воедно постоечката ситуација на источниот дел на Скопје е директна последица на истиот.

\footnotetext{
${ }^{8}$ Бакалчев, Минас, Домување како урбан фрагмент, необјавена докторска дисертација, стр. 70-71, 2004
} 

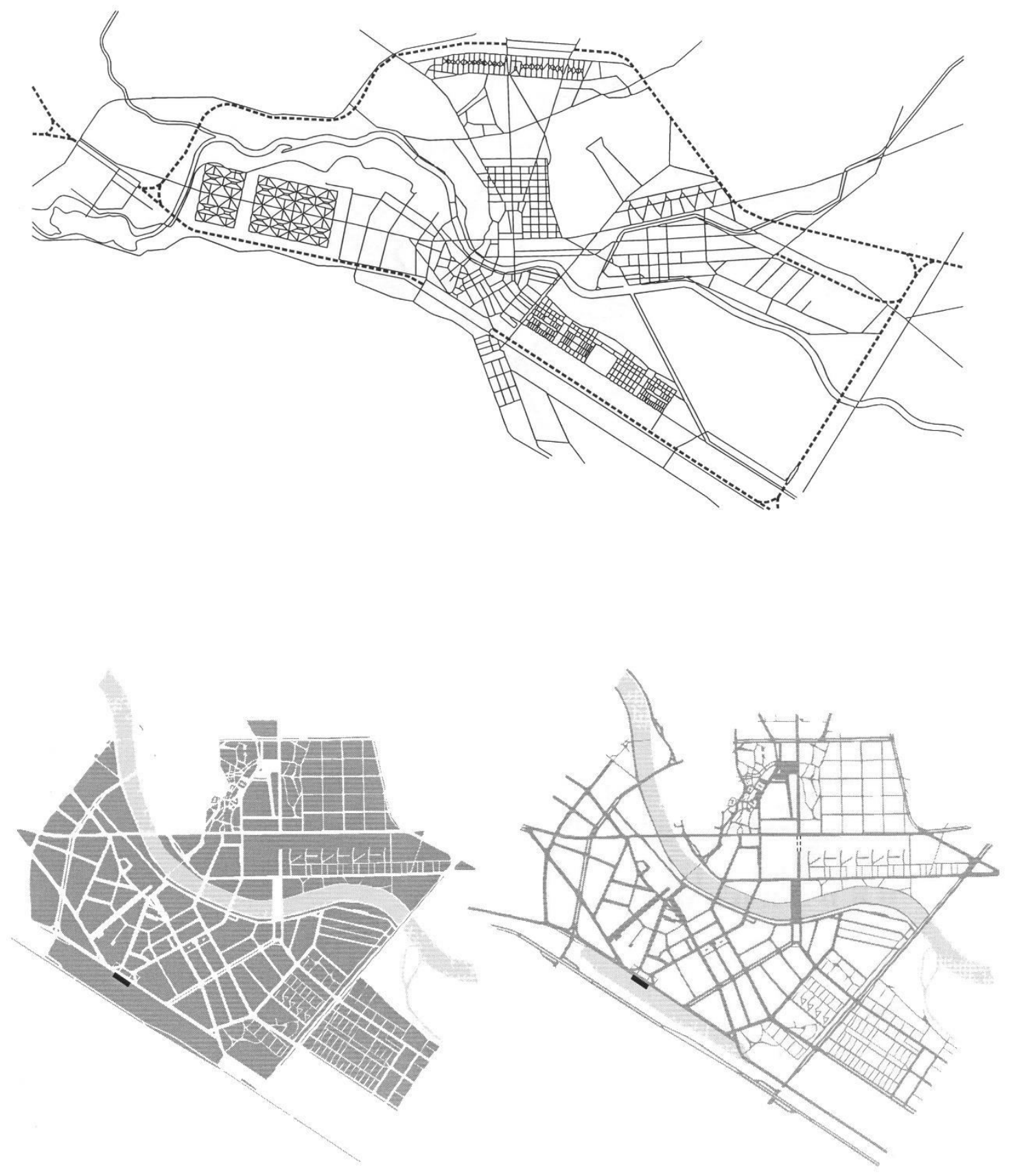

Сл. 26 Генерален регулационен план на Скопје, л. Кубеш (1948) Горе: Аксијален план Долу: Морфолошка анализа блоковска диференцијација во потесното централно подрачје 

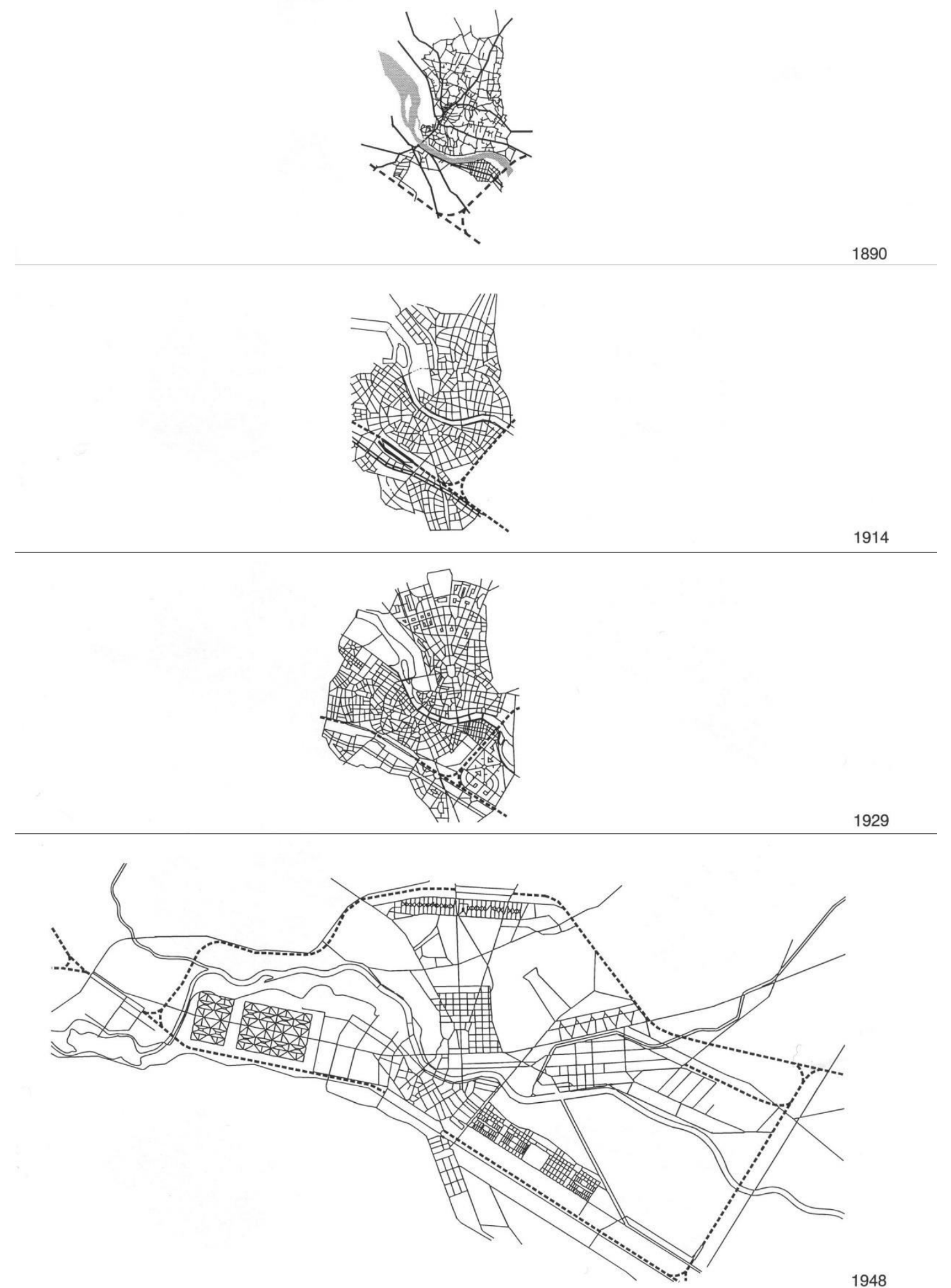

1948

Сл. 27 Структурални трансрормации на урбаниот грид; од радијален, радијално-концентричен, до линеарен модел 


\section{3. Скопје - инцизија}

\section{1 Скопје - Исток попречен профил}

Локацијата која е одбрана за интервенцијата е линиската екстензија на источниот дел од градот Скопје. Преку анализата на регулациониот план изработен од чехословачкиот архитект Лудек Кубеш во 1948 година, ја образложивме диференцијализацијата на градот на функционални зони кои комплетно го менуваат просторното искуство, во однос на предходните идеи и визии за трансформација на градот. Придржувајќи се на точно дефинираниот карактер на овие зони (според Атинската повелба на CIAM IV во 1933), Кубеш и неговите соработници му оставаат на Скопје една рамка, која од денешен аспект е јасно воочлива, иако фррагментарна по својата природа. Постојната состојба на оваа линеарна екстензија е фрормализирана во три зони; резиденцијалната зона покрај реката Вардар; индустриската зона и фрагменти од индивидуално домување; зоната наменета за образование и наука. Како што веќе го објаснивме процесот на брза урбанизација на урбаната структура на градот во предходните делови, овие зони веќе не се гранични зони на периферијата на градот, туку напротив, влегуваат во пошироката централна област. Со оглед на овој фракт, постои комуникациски, просторен и програмски дисконтинуитет на зоните во попречниот правец, затоа што тие постојат само како фрагменти од некоја урбана стратификација, фррагменти кои претставуваат дистинктивни морфолошки клетки од кои е создадена целината на градот Скопје. Секој од овие делови на градот егзистира самостојно без никаква допирна точка меѓусебе, почнувајќи од населбата Аеродром и колективното домување долж кејот на реката Вардар, 
зеленот појас на реката Вардар, индустриската зона заедно со фрагменти на ситна структура на куќи од населбата Ќерамидница до зоната наменета за образование, студентскиот дом “Стив Наумов” и парк-шумата “Гази Баба”. Линиската поделба исток-запад во овој дел на градот ја одредуваат реката Вардар со својот тек, железничката пруга и булеварот "Александар Македонски". Зоните кој што се тема на обработка во ова истражување се:

3.1.1 Зона 1 - Кеј на Вардар

3.1.2 Зона 2 - Неформални станбени џебови, населба "Ќерамидница"

3.1.3 Зона 3 - Индустрија

3.1.4 Зона 4 - "Скопски Саем", хотел "Континентал"

3.1.5 Зона 5 - Образование и наука

3.1.6 Зона 6 - Парк-шума “Гази Баба” 


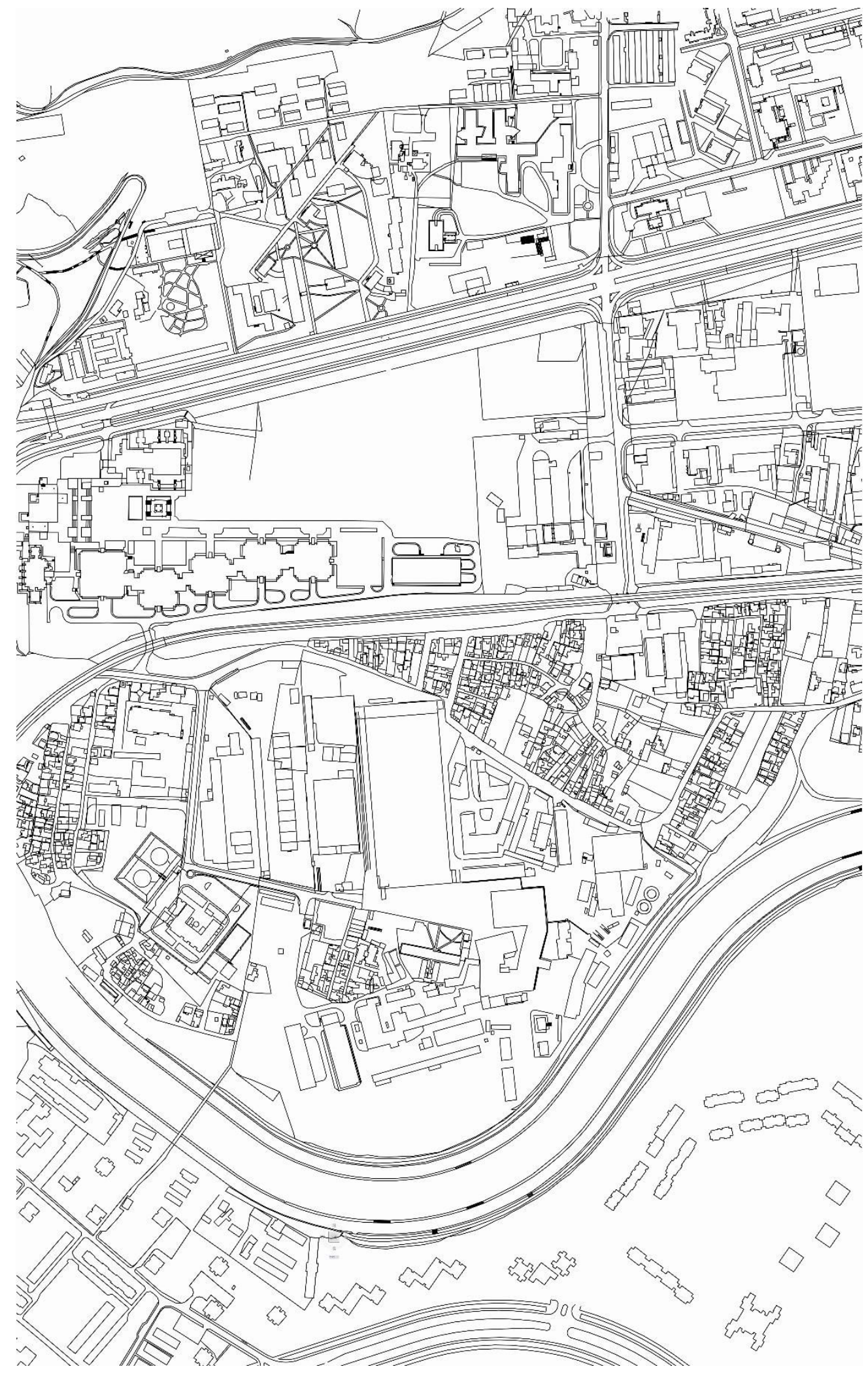

Сл. 28 Ситуација на делот од градот одбран за инстражувањето, Скопје-исток 


\subsection{1 Зона 1 - Кеј на Вардар}

Просторот кој го создава една водена површина која поминува низ урбана структура претставува најатрактивниот дел во самиот град. Тоа е главно зелена, рекреативна зона, и во зависност на поставеноста на градското ткаење во однос на реката и големината на самата река претставува конектор на различни зони. Во случајот на Скопје, реката Вардар и кејот се непроценлив дел од градот, минувајќи по целта негова должина. Елементи кои се јавуваат во зоната на кејот на Вардар, покрај рекративната патека, дрвореди и урбана опрема, се и спортски игралишта, урбана агрикултура, одгледување, продажба и хортикултурно уредување, паркови. 


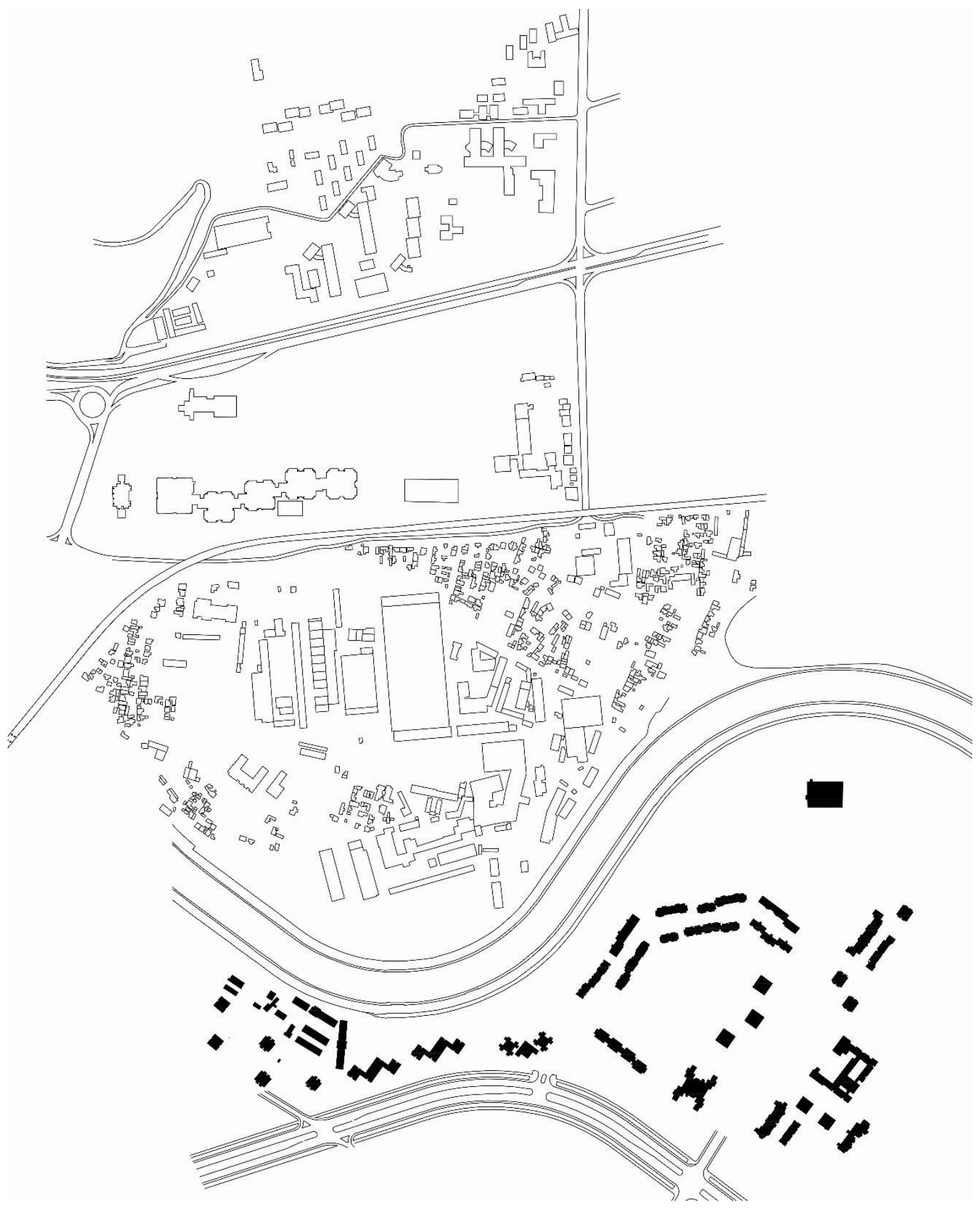

Сл. 29 Зона 1, Вардар 
3.1.2 Зона 2 - Неформални станбени џебови, населба “Ќерамидница”

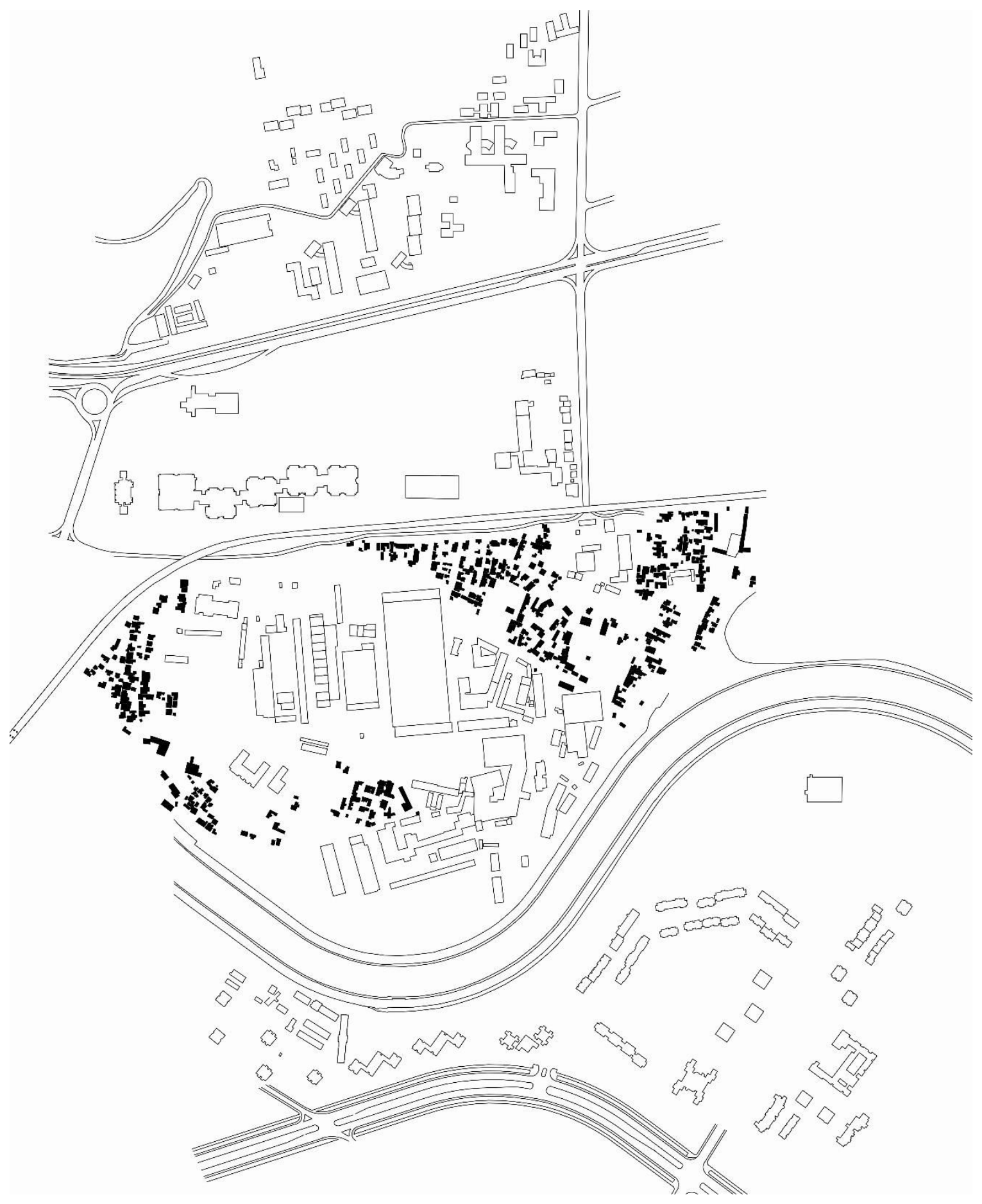

Сл. 30 Зона 2, неформални станбени чепови, населба "Ќерамидница" 


\subsection{3 Зона 3 - Индустрија}

Од аспект на индустријата, преку анализа на плановите и снимките на градот во историски рамки, можеме да увидиме дека со почетокот на линеарната експанзија во средината на XX век, главната концентрација на капацитетите за индустрија се појавуваат на источната страна на градот, од левиот брег на реката Вардар. Линиското ширење на градот во оска исток-запад како главна комуникациска линија и во однос на поставувањето на индустријата е поради доминантните правци на ветрот. Диференцирана е на две главни зони: градски сервиси, на левиот брег на Вардар, долж течењето на реката Вардар и појас на тешка индустрија, долж источната страна на железницата. Појасот на тешката индустрија е во комуникација со железницата/патната линија и станбената зона, формирајќи една локална линиска диспозиција на градот.

Конкретно на делот кој што се обработува во овој проект, се наоѓаат неколку индустриски капацитети: ФАС 11 Октомври, фрабрика "Бисерка", автокуќа “Механика" ООЗТ за ремонт на возила, АТП “Пролетер” - Скопје, Работна Организација “Коце Металец”, фабрика за хартија и амбалажа “Комуна”, Топлифрикација Скопје - Топлана Исток, фабрика “Глорија”, Работна Организација за промет со сите отпади на големо и мало "Наша Суровина". Со оглед на тоа што дел од овие капацитети не се повеќе во функција, може да се предвиди трансформација на истите и во поинаков вид на намена, особено затоа што во мал радиус се наоѓаат фрагментите од населбата Ќерамидница. Граници на оваа зона се реката Вардар од јужната и насипот на железничката пруга на северната страна. 


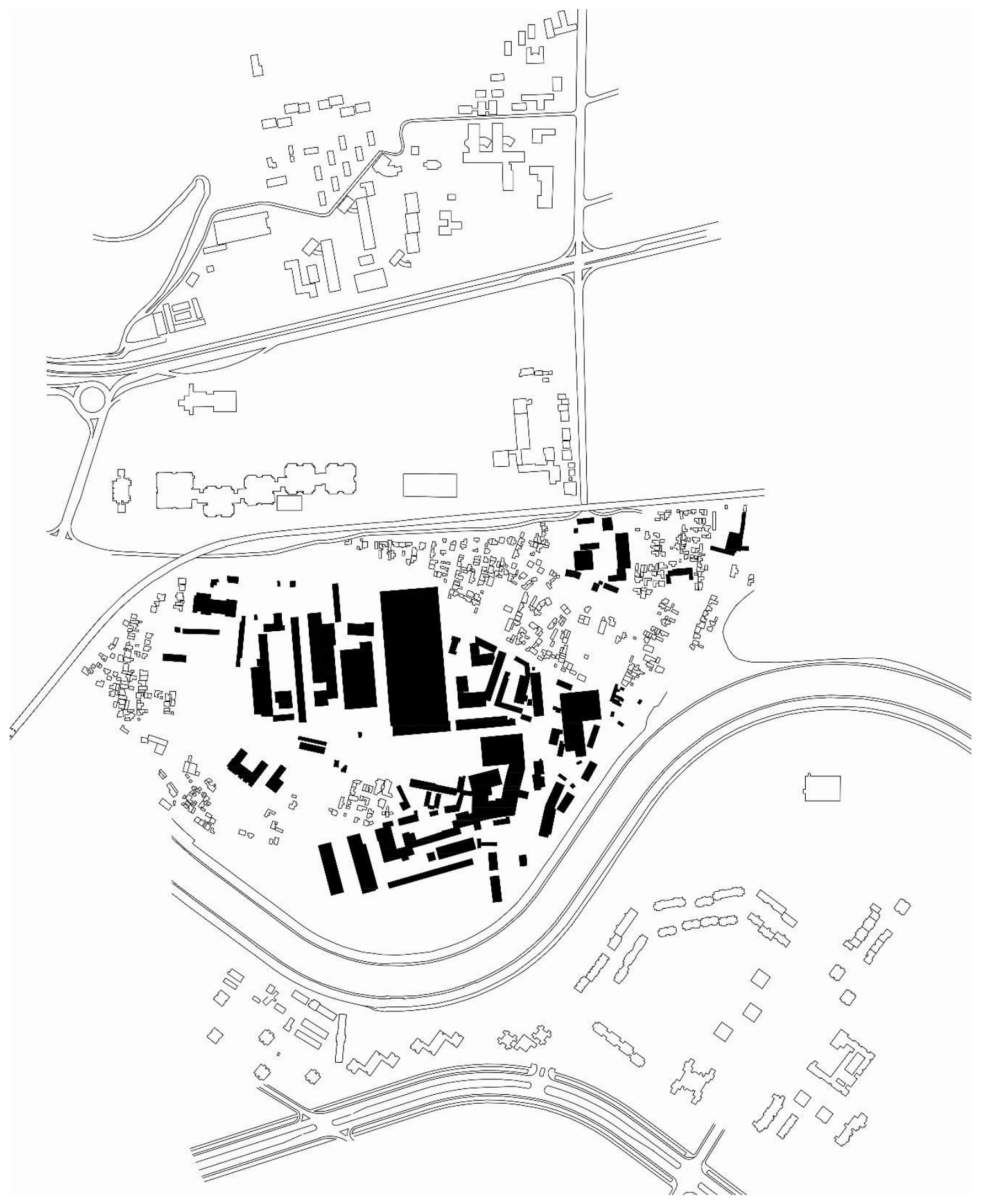

Сл. 31 Зона 3, индустрија 


\subsection{4 Зона 4 - “Скопски Саем”, хотел “Континентал”}

Оваа зона се надоврзува на индустриската зона иако е главно неизградена. Како главни физички структури тука се “Скопски Саем” и хотел “Континентал” и празна парцела во сопственост на “Југосуровина" - Скопје. Исто така се наоѓаат и некои помали угостителски и производни дејност на источната страна, долж улицата “Македонска Бригада". Како што предходно споменавме, во оваа зона се појавува единствениот отворен зелен простор кој има капацитет и предиспозиции да прими содржини кои од културен, рекреативен и општествен карактер. Поради тоа што сопственоста на земјиштето е на приватни сопственици, овој дел е комплетно затворен и недостапен и воопшто "не постои" во урбаната слика на градот. 


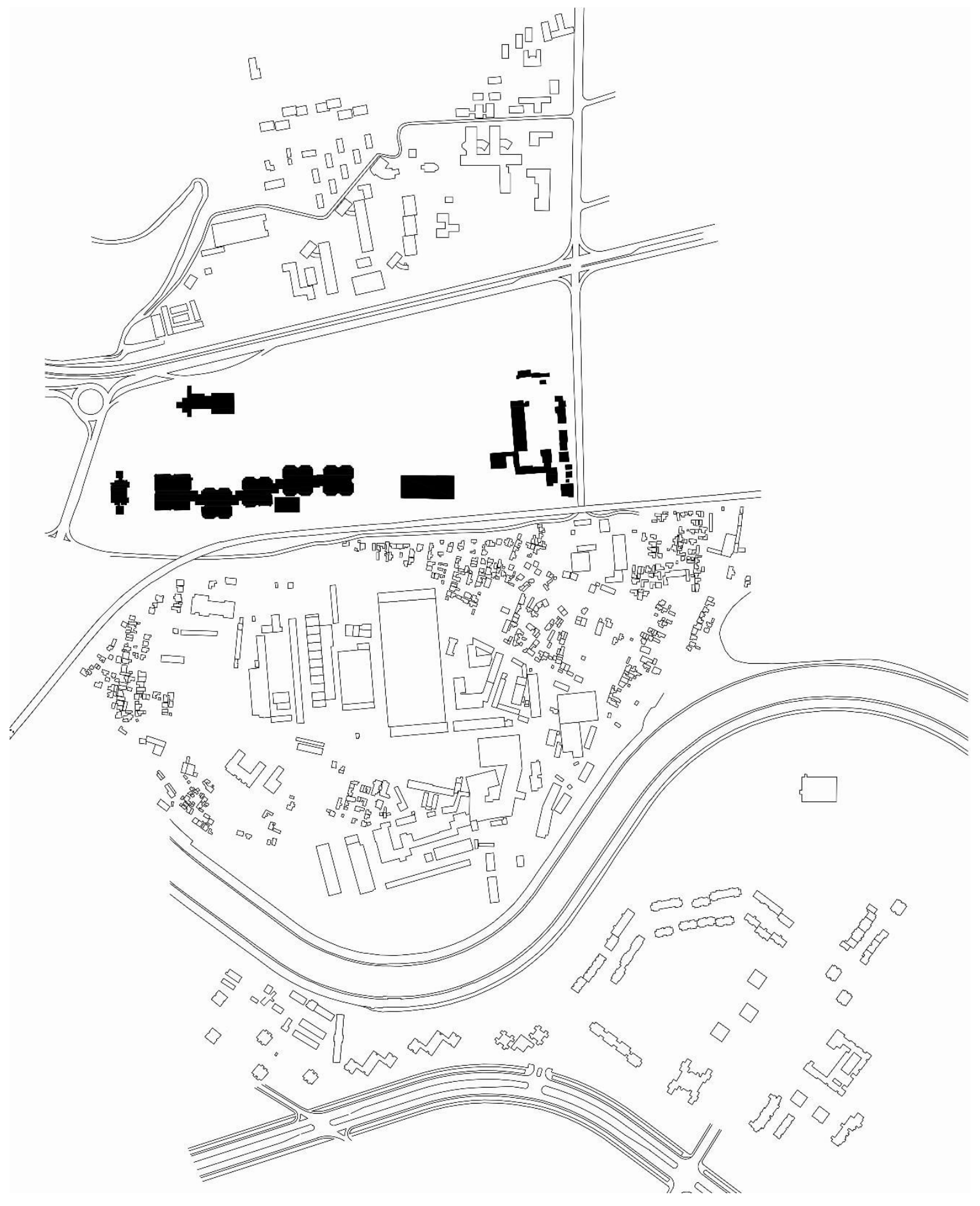

Сл. 32 зона 4, Скопски Саем 


\subsection{5 Зона 5 - Образование и наука}

Во оваа зона се наоѓаат: Студентскиот дом "Стив Наумов", Факултетот за Ветеринарна Медицина, Шумарски Факултет, Земјоделски Факултет и Институтот за Хемија.

Ова е многу значајна зона по својата природа, затоа што сеуште ги содржи аспектите претставени со генералниот регулационен план на Лудек Кубеш. На локацијата се наоѓаат слободно стоечки објекти кои заедно со зеленилото што ги обиколува прават една целина. Тоа најдобро се забележува на примерот на објектите проектирани од архитектот Славко Леви (Slavko Lowy), кои претставуваат три независни структури, дел од студентското домување, проектирани во духот на планот на Кубеш. Леви ги проектирал овие објеки во средината на XX век, кога и престојувал и работел во Скопје, од 1950 до 1953 година. 


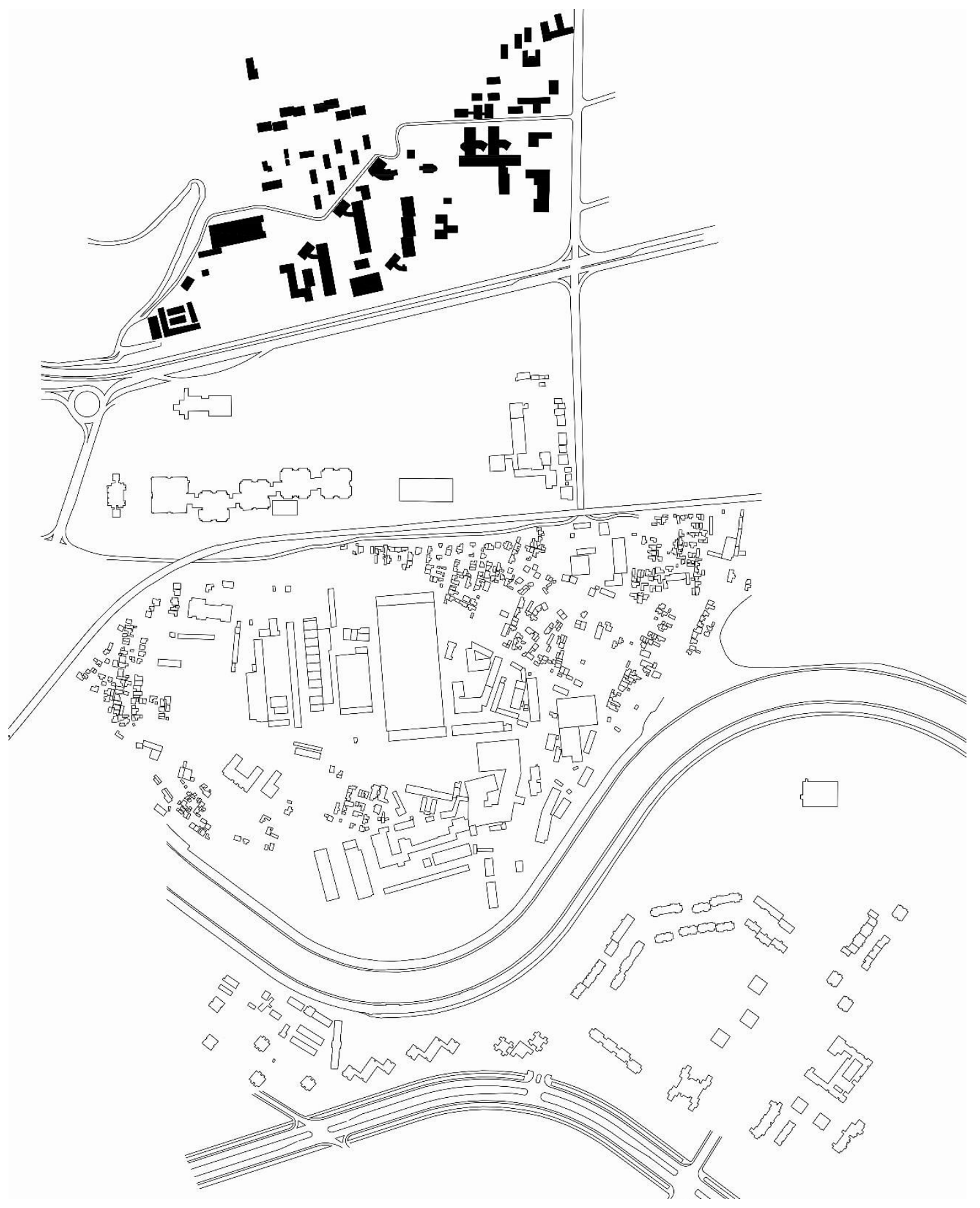

Сл. 33 Зона 5, образование и наука 


\subsection{6 Зона 6 - Парк-шума "Гази Баба"}

Парк - шумата Гази Баба претставува навистина посебен феномен, бидејќи со својата големина во однос на блискоста на централното урбано подрачје егзистира како квалитет кој ретко го поседуваат други метрополи. Иако се работи за вештачки создадена природна формација, претставува целосно оформен биотоп во урбаното ткаење. Поради нејзиното огромно значење со Одлука на Градот Скопје, шумата на локалитетот Гази Баба е заштитена како “карактеристичен пејсаж”. Паркот - шума е оформен во средината на XX век со санитарно - хигиенска намена на заштита од емисиите од поранешната Железарница и нивно спречување да се дисперзираат кон внатрешноста на градот која тогаш била со значително помали димензии. Сегашната диспозиција навлегува и во поширокото централно подрачје и покрај основната функција, надополнета е со функции од културно - воспитен и туристичко - рекреативен карактер.

Според информации од официјалната интернет страна на општина Гази Баба, паркот има површина од 102,44 хектари и се јавуваат голем број на лисјарски и четинарски видови на дрвја и грмушки, а најраспространети се црниот бор, јасенот и дабот. Значењето на оваа шума изразено во бројки, според истражување на општината изгледа вака: врзува 1.323,6 тони јаглероден диоксид, ослободува 970,64 тони кослород, филтрира 5.294 тони прашина, абсорбира 8,824 килограми сулфур диоксид од воздухот и исто толку јаглероден моноксид и азотни оксиди. Ова се податоци за да ни го кажат непроценливото значење на карактеристичниот пејсаж на паркот - шума Гази Баба. 


\section{2 Скопје - Исток инцизија, презентација на методот на интервенција}

Проектот е хипотеза за нефигуративен архитектонски јазик за градот. Поимот граница се јавува во однос на дисконтинуитетот на линеарното ширење на градот. Со суперпонирање на попречна линеарна структура која од една страна опстојува независно, а од друга страна воспоставува интеграција со постојниот фррагментиран контекст. Таа нова линија помага за согледување на структурата на урбаната морфологија. Новата линеарна структура се суперпонира на градот, но не ја попречува нормалната циркулација на истиот, за да во исто време претставува дистрибутор и интегратор на градските фрагменти во спротивниот правец.

Цел на интервенцијата е реинтегрирање на фрагментираниот контекст на урбаното ткиво на архитектонско ниво - нови модели на домување, нова диспозиција на јавните програми на постојните просторно-програмски ситуации.

Интервенцијата е принцип кој може да биде повторен на различни локации во зависност на условите и потребите што ги нуди и се потребни на самата локација.

Постојат два основи елементи од кои се состои проектот:

- линија 1500 - каде што се наоѓаат единиците за домување, систем на транспорт

- трака-површина 1500х60м - во која има рекреативни содржини, зелени површини, агрикултура, рекреативна патека. 
Основни поставки на интервенцијата:

- пресекување на градот со должина од 1500 метри метри во која се суперпонира мостовска структура во која се вметнати фрлексибилни единици за живеење над кои се наоѓа транспортно средство за брза комуникација долж мостот.

- поврзување на делови од градот; парк-шума “Гази Баба” со кејот на реката Вардар; поврзување на зелените површини, создавање на нова алтернативна рекреативна патека и внесување на зеленило долж оската во самиот град; обработливо земјиште, агрикултура;

Проектот се содржи од различни елементи, фрагменти, од кој секој има посебно значење и важност, своја цел во создавањето на просторот, но најважна е целовитоста која ја создаваат сите овие елементи и нивното заедничко функционирање за фрормирање на една целосна слика и доживување. Најважна е компатибилноста на елементите во процесот на создавањето на едно целосно сетилното и чувствено искуство. 


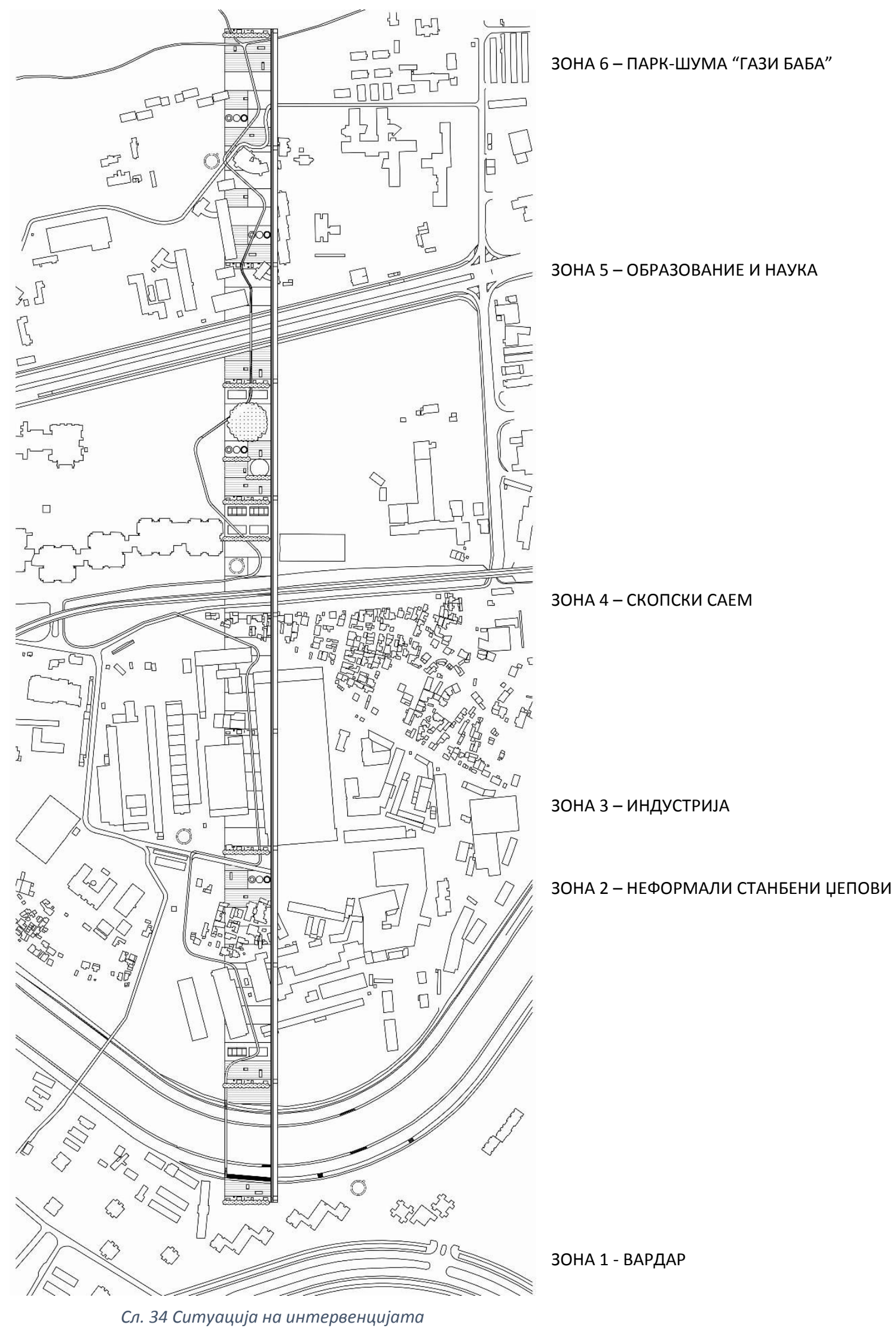




\subsection{1 Линија 1500м - домување}

Мостот, по самата природа, претставува елемент што поврзува и има чистина и искреност во самиот потег. Главен аспект е функционалноста на структурата. Прашањето е како да се добие една програмска и просторна интеграција на различните зони, воедно да се предложи нов тип на станбена структура. Предлогот е да се суперпонира една челична мостовска конструкција како наједноставен просторен систем, кој е флексибилен и може да овозможи прилагодувања во однос на фрагментиранта површина над која се наоѓа. Примарна фрункција на оваа мостовска конструкција е да обезбеди трансформација на станбена структура со што е можно помала физичка интеракција на самата површина од аспект на деструкција на постојното ткиво. Ова е така поради два важни фракти: 1. потребна е современа реквалификација на делови на станбената структура во урбаната морфологија на градот,

2. станбениот фррагмент и неговите жители на кои што се однесува ова истражување постои, живее и расте во текот на долг временски период, што ни укажува и на многу позитивни елементи иако е во потреба за современа трансформација. Земајќи ги во предвид овие квалитети, за најсоодветен метод на интервенција е избран методот на суперпонирање на структура која ќе содржи станбени единици.

Секундарна, но не и помалку релевантна, е функцијата на мост или поврзување. Во предходниот дел се дефинирани зоните кои се предмет на истражување и потребата за попречно поврзување на истите, со што сега мостот претставува една поливалентна инфрраструктура која овозможува преку истата да се 
остваруваат различни функции. Допирот на мостовската конструкција со подлогата е суптилен и се однесува на конкретните урбани морфологии. Тоа значи дека локација на мостовската конструкција е хипотетичка, односно, во зависност од постоечката состојба. Претпоставената конкретна локација на конструкцијата во ова истражување е избрана од аспект на намената на постојните изградени ткива, функционалноста на истите и можноста за нивна трансформација. Објектите кои се трансформираат се напуштени хали од затворени фрабрики или било какви други нефункционални, неформални структури.

Основната стуктурална единица на мостовската конструкција е со димензии: ширина 9 метри, должина 152,4 метри и висина 30 метри. Во средината се наоѓа спрег со димензии 8x9 кој го укрутува целиот систем и во него се јавуваат вертикалните комуникации; од двете страни на тој спрег се шират по 72 метри конструкција која на краевите е потпрена на столбови кои меѓусебно се зајакнати; тоа ја сочинува основната структурална единица, со што истата може бесконечно да се повторува по должина. Должината на мостовската конструкција во предложеното истражување е составена од десет основни структурални единици и изнесува 1532 метри.

Ширината на мостот, како што напоменавме, е 9 метри и во него се сместени единиците за домување. Самата површина е поделена на два дела: 3 метри патека и 6 метри единица за домување. Единиците за домување се разликуваат, постојат пет основни типа и четири комбинации на овие типа, а истите графички се објаснети во делот - каталог на станбените единици. Единиците се со 
максимална висина од П+2, а минимална само приземје. Димензијата во основа на една единица е 5 × 5,6 метри, со сопствен влезен дел од 2,80 × 5,6 метри. Исто така постои можност за поврзување на две или повеќе единици.

Последната функција што ја има мостовската конструкција е брзиот транспорт во вид на елетронски подвижен вагон, налик на метро, со помал капацитет, кој се наоѓ над челичната конструкција. Овој транспорт функционира така што се движи на шина во два правци од точка А (кеј на река Вардар) до точка Б (парк - шума Гази Баба) и обратно.

Овој гест на суперпонирање на мостовска конструкција може да го сметаме како стратификација на фрагмент на постојната ситуација на градот Скопје, чија структура во принцип е збир или целина на фрагменти. Важно е уште еднаш да се напомене интегрирачката природа на еден ваков фрагмент, кој според димензиите и својата природа да вкрсти повеќе фрункции во себе, може да се десинира и како мега - структура. 


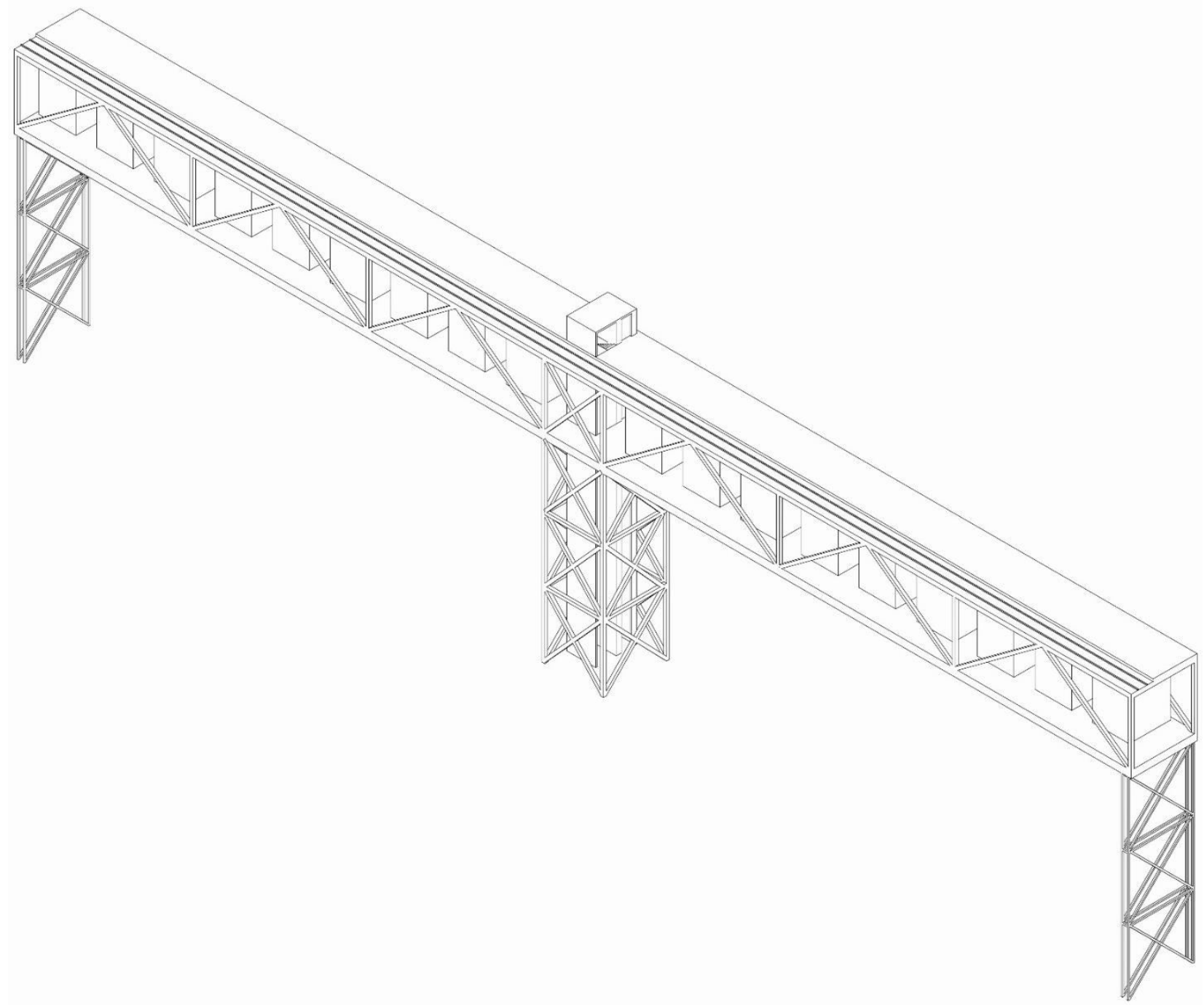

Сл. 35 Аксонометрија на основна конструктивна единица 

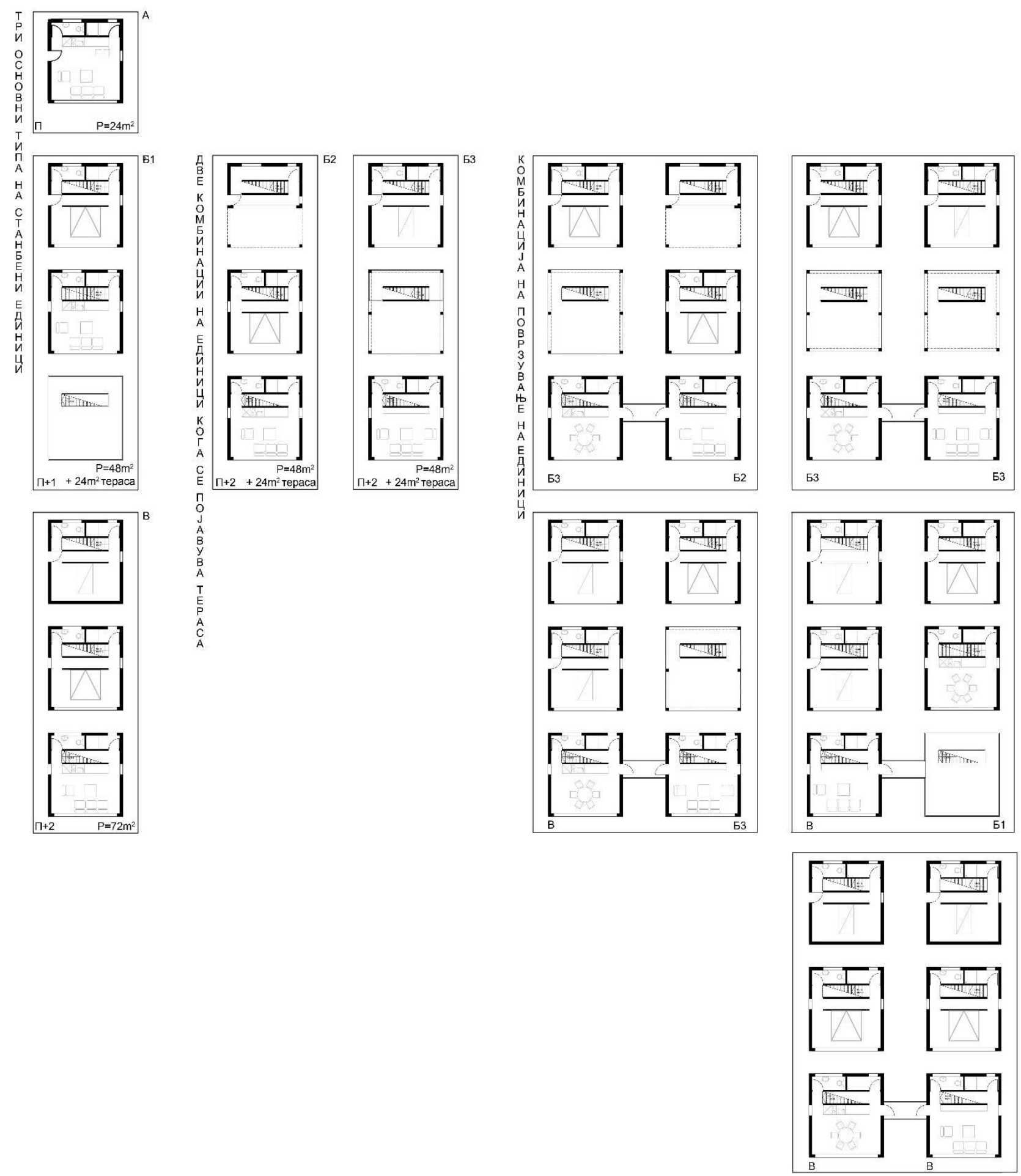

Сл. 36 Каталог на станбени единици 


\subsection{2 Површина-трака $1500 \times 60 \mathrm{M}$}

Димензии на модул 24х60 и 8х60 (каде што се појавува спрегот за укрутување на мостовската конструкција); модулот произлегува од димензиите на распонот на мостовската конструкција; модулот може да се дели или зголемува сразмерно на пола модул $24 \times 30$, или два модули $48 \times 60$. Во рамките на модулот се внесува содржината во однос на постоечката состојба.

Оваа површина може да се постави на различни локации во зависност од условите од самата состојба и од резултатот што сакаме да го постигнеме. Локацијата зависи од физичката структура што е цел за обработка односно е цел на некаква трансфомација или интегрирање со новата структура. Ова може да зависи од намената на објектите, состојбата на истите па дури и сопственоста и можноста за нивна адаптација. Целта е создавање на една рамка од 1500 метри на 60 метри ( трака која што ја менува ширината во зависност од контекстот), во која постепено ќе се имплементираат програмите кои што предходно се наведени. Концептот нема временска рамка, т.е. нема одредена динамика на исполнување на процесите и истите подлежат директно на жителите на новоформираната структура како и на жителите од околината. Концептот е претпоставен според визија за еден поинаков урбан простор кој поттикнува самосвесна реакција кај жителите за создавање на хумани места за живеење, урбани простори, архетипски места кои се врежани во нас, во некоја наша урбана или рурална меморија. 
Елементи и содржини од кои е создадена лентата од 1500x60 метри се:

- агрикултура

- објекти за одржување на агрикултурата и зеленилото

- велосипедско-пешачка патека

- плато / рекреација

- плато / продажба на производи

- кула-паркинг

- пикник површини

- пренаменети / трансформирани објекти

Зеленилото во урбаните средини е можеби главен предуслов за квалитетот на живот во еден град, нешто што се почесто се губи со големата експанизја на европските градови. Исто така и активноста и креативноста на жителите на спонтано создавање и креирање на јавни простори од различен карактер е оневозможена баш поради овој фракт.

Кристофрер Александер (Christopher Alexander) во неговото дело “A Pattern Language" кое е книга-водич за луѓето да можат сами да ја дизајнираат самата куќа, улица и својата заедница, нуди еден “јазик” за создавање на просторот, една мрежа од која може да се извадат различни фрагменти кои би биле најкорисни за корисникот и да се создаде една индивидуална шема која ќе помогне во креирањето на сопствениот проект. Неколку елементи може да се искористат како елементи кои ќе помогнат во процесот на проектирање; Александер пишува: 
“Градините и малите јавни паркови не даваат доловна заштита од бучавата доколку не се добро заштитени.

Луѓето имаат од потреба на контакт со дрва, растенија и вода. На некој начин, тешко е да се опише, луѓето се чувствуваат целосни во присуство на природа, можат да продрат подлабоко во себеси и да исцрпат енергија од природата. Во градовите, градините и малите паркови се обидуваат да го решат овој проблем, но најчесто се многу блиску до сообраќајниците, бучава и објекти и влијанието на природата е целосно изгубено. За да биде навистина корисно, во најдлабоката психолошка смисла, мора да им се се овозможи на луѓето допирна точка со природата во која ќе бидат заштитени од погледот и бучавата на сообраќајот и урбаните звуци. Потребно е некакво затворање за да се заштити ентериерот на една тивка природна средина од погледите и звуците на градот. Ако се работи за голема градина или парк, затворањето може да биде суптилно, можеби само растенија, грмушки, дрва, денивелација на теренот, но што помала е градината, поцврсто и дефинирано треба да биде затворањето.

Овие аспекти кои ги препознава Александер, се секојдневи во урбаниот живот, но се работи за степенот на перцепција на жителите на околината во која живеат; елементи кои се едноставни по својата природа, но не функионираат во секаков контекст и конфигурација. Овие елементи, иако делуваат изолирани, претставуаат елементарни фрагменти од една поголема слика во обликувањето на просторот во кој живееме. Александер пишува: “Кога дрвата се засадени или откорнати без 
да се знае значењето на посебните места кои тие ги создаваат, тие се како мртви за луѓето што им се потребни."”

Урбаната агрикултура обезбедува комплементарни стратегии за да се намали урбаната сиромаштија и да се подобри управувањето со урбаната околина. Урбаната агрикултура игра огромна улога во подобрувањето на обезбедувањето на храна во урбаните средини, бидејќи трошоците за снабдување и дистрибуција на храната која се произведува во руралните средини, а се наменети за урбаните средини, континуирано се зголемува и нема да ја задоволи побарувачката, особено на сиромашниот сектор од популацијата. Покрај обезбедувањето на храна, урбаната агрикултура допринесува за локалниот економски развој, намалување на сиромаштијата и социјално вклучување на сиромашните лица што живеат во урбани средини, како и за позеленување на градот и продуктивна реупотреба на урбаниот отпад.

Економскиот аспект е исто така многу важен. Со растење на храната во сопствена бавча се заштедува на потрошувачка на храна; луѓе кои живеат со ниски примања трошат околу 50-60\% на храна. Исто така, продавајќи го својот продукт носи приход. Покрај економскиот бенефит што го продуција урбаната агрикултура, таа го стимулира развојот на поврзани микро-претпријатија: производството на производи како влезен параметар и процесирање, пакување и маркетинг како излезни параметри. Постоењето на активностите или услугите од страна на овие претпријатија како целина, му ја должат на урбаната агрикултура.

\footnotetext{
${ }^{9}$ Alexander, Christopher, A Pattern Language, Oxford University Press, New York, cтp.799, 1977
} 
Влезното производство и достава може да вклучува активности како собирање и производство на органски пестициди, фрабрикација на орудија, купување и носење на хемиски ѓубрива итн.

Свежите или преработените производи можат да бидат достапни за продажба веднаш до местото каде што се произведуваат со што се гарантира кавалитетот на истите.

Локалните системи за производство на храна градат една самоодржлива прехрамбена економија во која продукцијата на храна, обработката, дистрибуцијата и потрошувачката доаѓаат заедно за подобрување на економското, еколошкото и социјалното здравје на едно место. Тие обезбедуваат вработувања, генерираат приходи и поддржуваат социјална еднаквост. Важноста за внесување на агрикултурата во градот како неопходен дел од аспект на зголемување на свеста за одржлививоста и еколошкиот аспект е од суштинско значење на инднината на нашето живеење. Брзата урбанизација е предизвик не само за урбаните туку и за руралните средини. Миграцијата на населението од руралните во урбаните средини е голем проблем за македонското село, а воедно и произдводсвото и агрикултурата. Агрикултурата во урбана средина значи поддршка на земјоделството и треба да поттикне самоорганизирање на граѓаните во една заедничка свест за подобрување на животот и квалитетот на исхраната. Ланецот за производство, продажба и конзумирање на продуктите е во корелација со домувањето. Жителите што живеат во мостот и останатите граѓани од градот Скопје можат да си обезбедат (изнајмат) свое земјиште за обработка. Многу важно е да се создаде социјална свест, која би го олеснила зајакнувањето на 
врските помеѓу сите учесници во овој ланец. Општините и многу други

организации можат многу да помогнат на локално ниво за развивање на урбаната агрикултура.

Урбаната агрикултура е дел од урбаниот еколкошки систем и игра огромна улога во системот за одржување на средината. Најпрво, град што расте би продуцирал се повеќе и повеќе отпадна вода и органски отпад. За повеќето големи градови отстранувањето на отпадите претставува голем проблем. Урбаната агрикултура може делумно да го реши овој проблем претворајќи ги овие урбани отпади во продуктивни ресурси.

Во проектот, обележани се деловите од лентата кои се предвидени за одгледување на агрикултура и поделени со мрежа од 3×3 метри. Оваа мрежа ја одредувала границата на сопственост на парцелите, во зависност од површината на изнајмената квадратура на фрертилно земјиште. Дозволата за користење на земјиштето е на принципот на изнајмување. Можноста за колективно одгледување на агрикултура овозможува олеснување во однос на самата физичка работа, фринансиските трошоци на потрошен материјал и алати. 


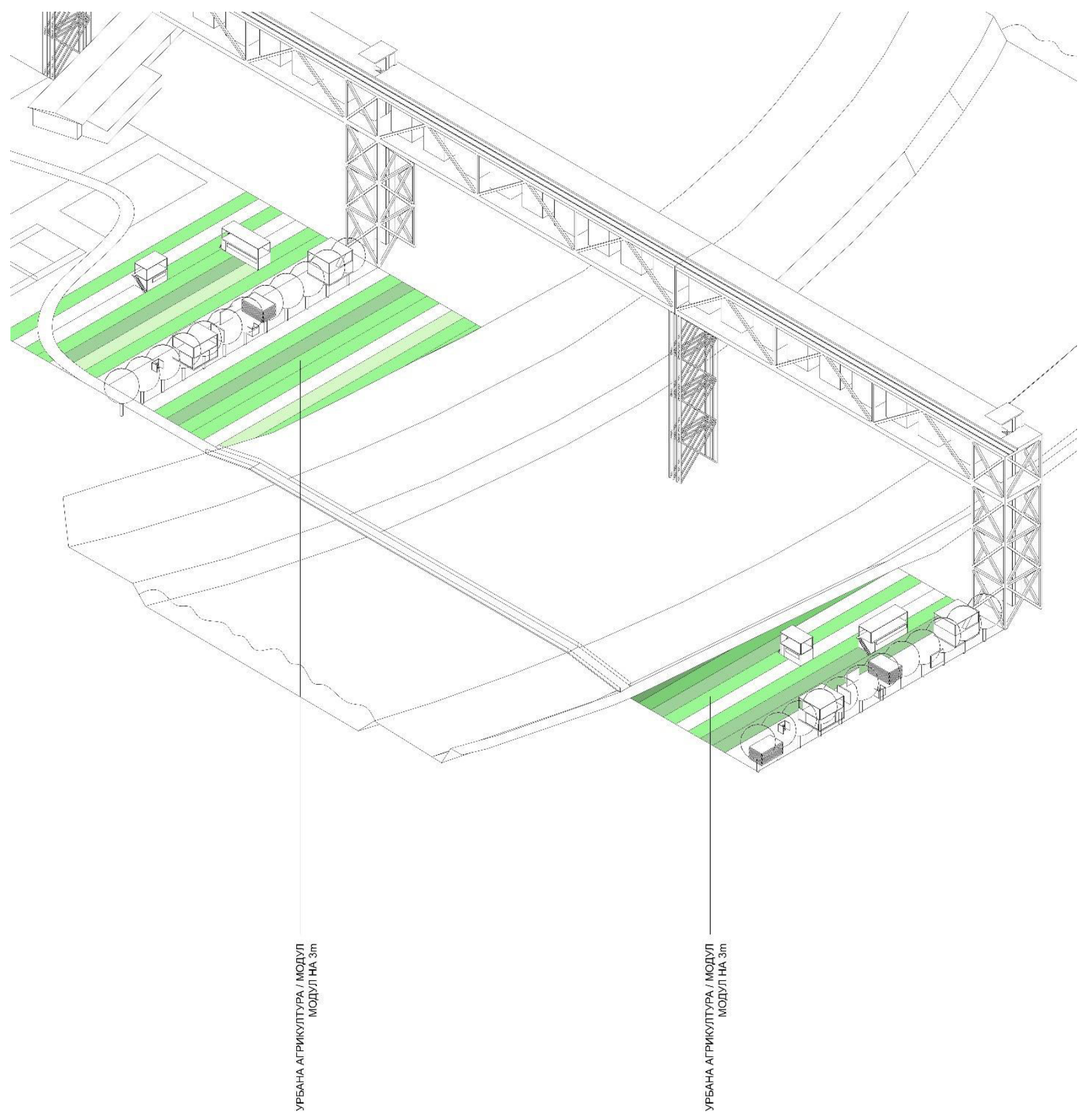

Сл. 37 Аксонометрија на дел од интервенцијата, урбана агрикултура 
Објекти за одржување на агрикултурата и зеленилото - објектите кои се предвидени во овој фрагмент служат како сервисни простории за чување на алат, материјали, ѓубриво, семе и слично. Постојат две димензии на овие објекти: 8 × 3 метри и 5 x 3 метри. Објектите се приземни, со можност за искористување на кровната површина до која се качува со скали, поставени на бочната страна од објектот. Кровната површина е заштитена со надстрешница и на неа може да се одгледуваат цвеќиња или да служи само како видиковец за набљудување. Објектите се од полујавен карактер, односно може да ги користат сите луѓе кои што имаат изнајмено земјиште за изработка.

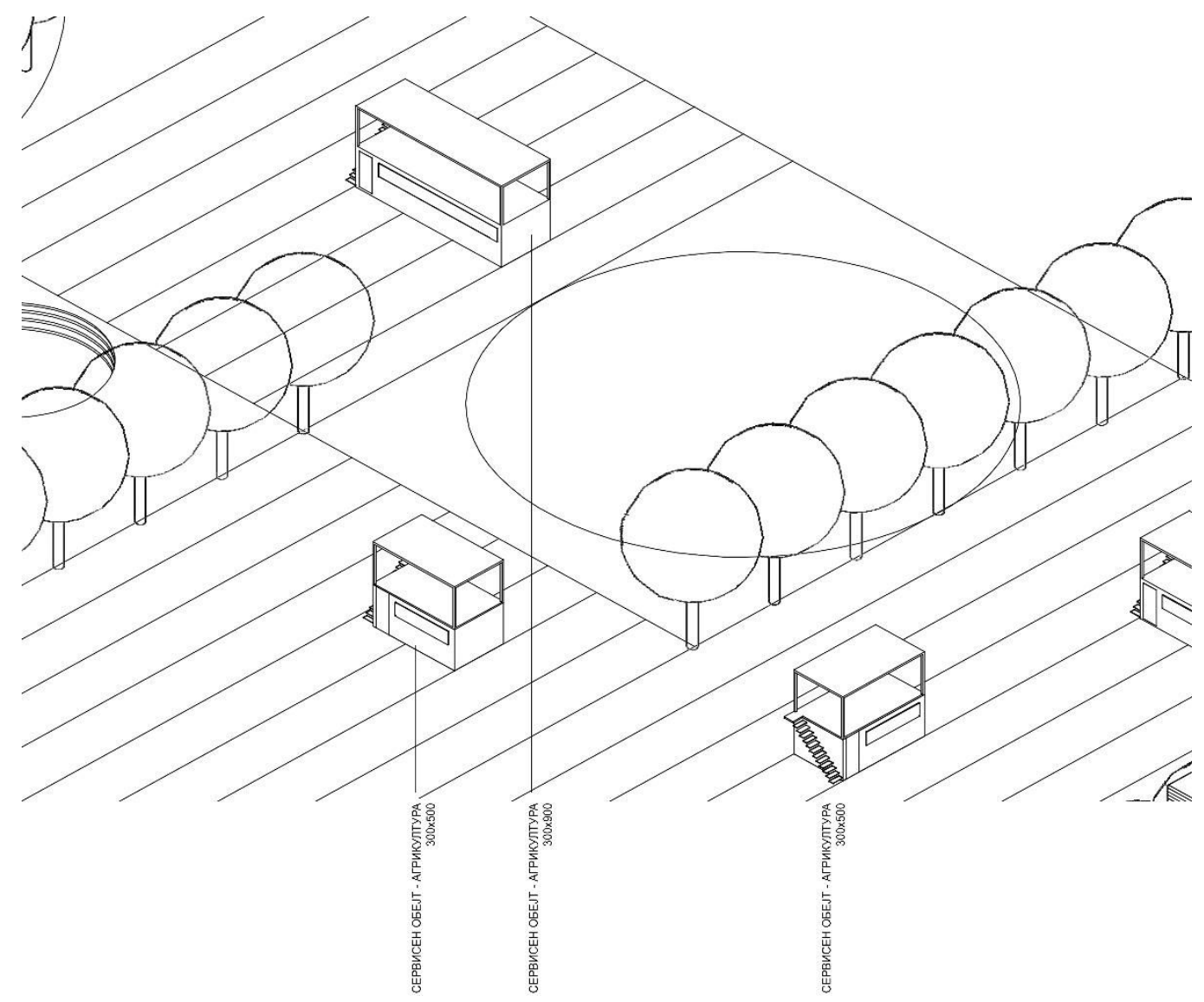

Сл. 38 Аксонометрија на дел од интервенцијата, сервисни објекти за урбана агрикултура 
Велосипедско-пешачка патека - оваа патека претставува алтернативна рута која ги поврзува двете најоддалечени точки, кејот на Вардар и парк-шумата “Гази Баба", а измеѓу и сите останати фрагменти низ кои поминува. Оваа траса може да се нарече авантуристичка, бидејќи по својата должина поминува низ различни зони од градот, нудејќи интересни нови искуства низ секоја од нив. На пример, велосипедската авантура може да започне од кејот на реката Вардар каде што со мост се преминува на левата страна од брегот и се влегува во индустриската зона каде што трасата делумно следи постоечка патека, но на моменти минува низ тесни улички, многу блиску до индустриските хангари. Возењето продолжува со заобиколување на насипот од железничката пруга од постоечкиот подвозник каде што се влегува во следната зона. Во следната зона откако ќе поминеме низ скопскиот саем на левата и еден индустриски објект на десната страна, пред нас се отвора една пространа зелена површина, повремено испрекината со формација на високи дрва, спортски игралишта и јавни места за уживање во природата. Овде нема никаква допирна точка со урбаното. Панорамата ја сочинуваат контурите на градот, но изолацијата е постигната со поставување на високо зеленило, денивелација на земјиштето и високи “природни” sидови. Возиме низ посадените, разнобојни плодови и ископаното земјиште околу нас. Поминувајќи го булеварот “Александар Македонски” влегуваме во следната зона директно во една густа околина на зеленило кое е обиколено со неколку ниски, но долги објекти. Тука веќе се чувствува близината на шумата, се гледаат крошните на дрвјата во далечината. Патеката не води до крајот на цивилизацијата; пред нас густа шума со високи дрва, чувство на неизвесност. Додека се пробиваме низ 
стеблата, стигнуваме до чистинка и пресек со уште една патека. Раскрсница.

Погледот одзади ни нуди уште едно изненадување; со искачување од околу дваесеттина метри низ густите стабла, го гледаме Скопје. На нас останува дали ќе продолжиме да возиме понатаму низ шумата или ќе се вратиме назад.

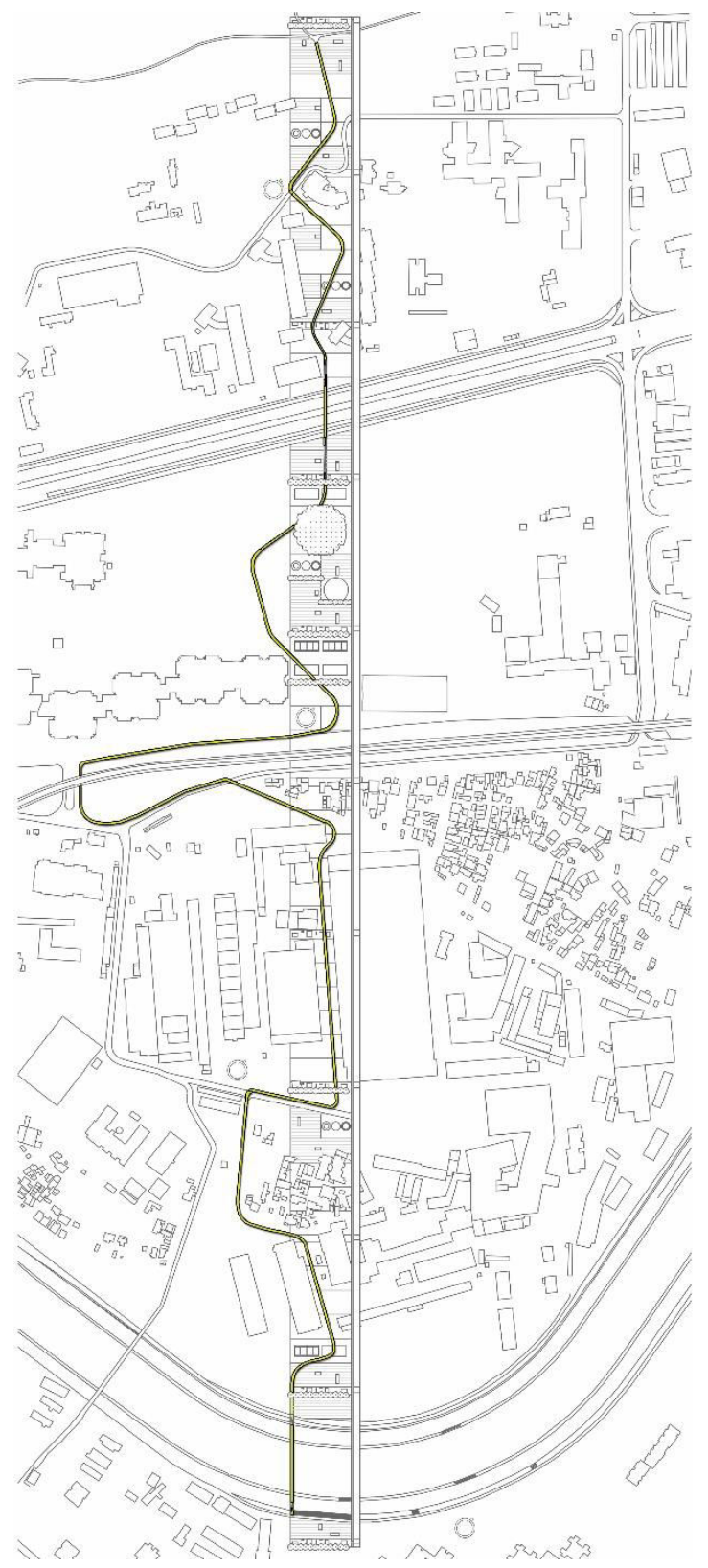

Сл. 39 Траекторија на велосипедско-пешачката патека 
Плато / рекреација, седење, одмор - претпоставената мрежа од 24х60 метри во себе содржи различни содржини и во зависност на истите може да се зголеми или намали. Местата за седење и одмор се од типот на отворени, мултифункционални простори - платоа, кои се со кружни форми и најчесто доаѓаат во фрормација на три помали круга или еден поголем круг. Кога се во фрормација, трите круга се од различна природа; едниот е денивелиран и е целосно исполнет со песок, каде што може да си играат деца, возрасни да кампуваат и да се сончаат; другиот е исполнет со вода - базен/водена површина и третиот е скалесто, амфитеатрално изграден, вкопан во земјата. Различни површини за различна употреба, кои можат лесно да се трансформираат и прилагодат на креативноста на жителите и корисниците.

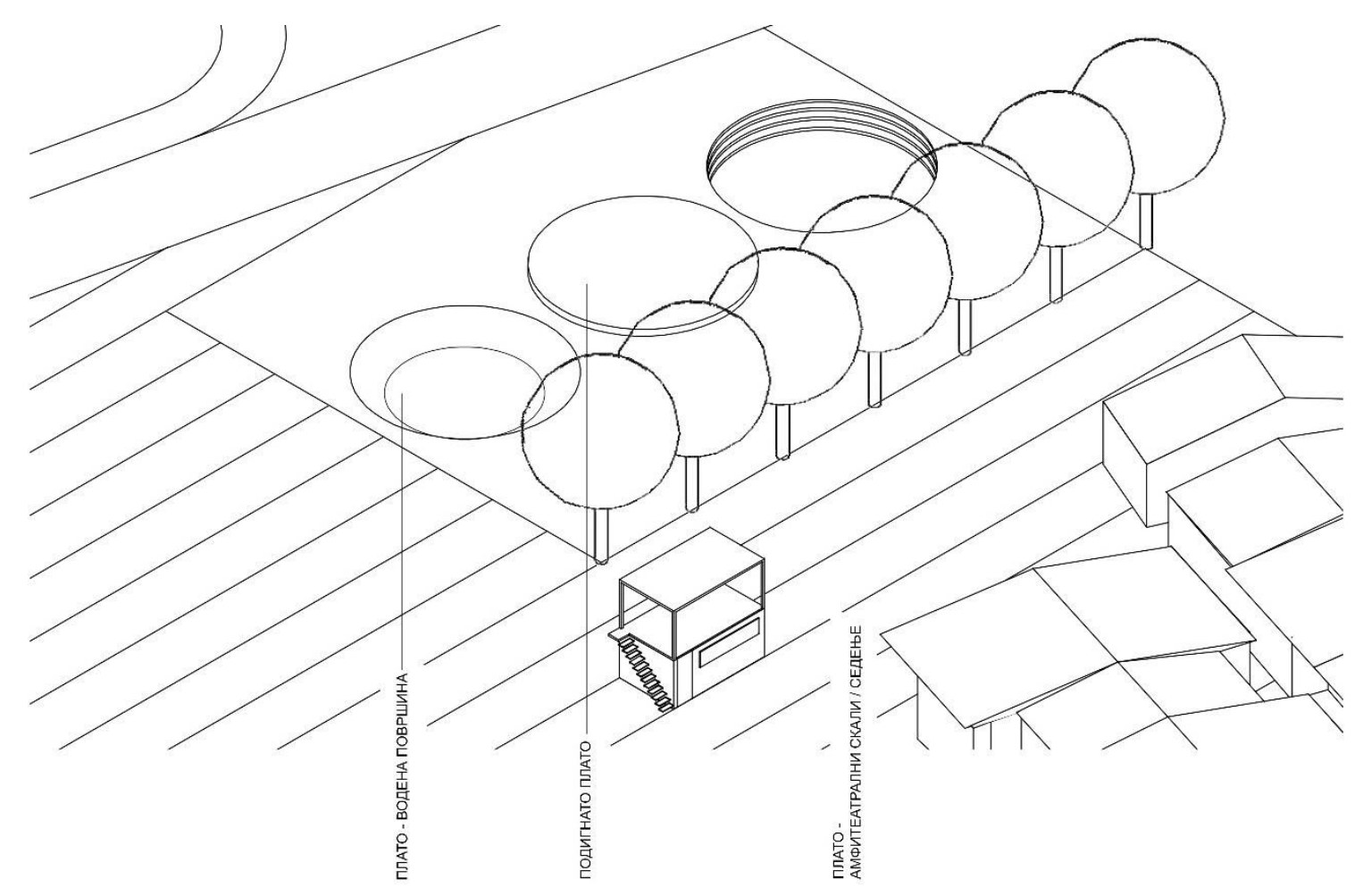

Сл. 40 Аксонометрија на дел од интервенцијата, плато - рекреација, седење, одмор 
Плато / продажба на производи - во точката агрикултура беше објаснет процесот во кој одредена површина од земјиштето се користи за одгледување на земјоделски култури се со цел да се создаде една еколошка, економска, самоодржлива заедница. Плодовите ќе се продаваат како свежи или делумно обработени производи на места, платоа за таква намена во рамките на мрежата на лентата. Димензијата на мрежата наменета за плато за продажба на производите е еднаква на - 8х60 метри; и се јавува во корелација со вертикалната комуникација на мостот односно на местата од лентата каде што од мостот се спуштаат скалишното јадро и лифтовите, односно каде што се јавува спрегот. Со ова се овозможува лесна комуникација до овие места, како за жителите од мостот така и за оние што се задолжени за одгледување на земјата и за посетителите. Платото се состои од мали објекти со различна намена. Објекти стакларници; одгледување и продажба на цвеќиња, објекти за продажба на производи поврзани со агрикутурата и земјоделството како семиња, алати, билна-аптека и слично. Продажбата на свежите производи се врши на отворениот простор околу овие објекти, на неформален начин на импровизирани тезги. Целта е да се создаде место налик на пазар, каде што ќе можат да се најдат производи од различен карактер. 


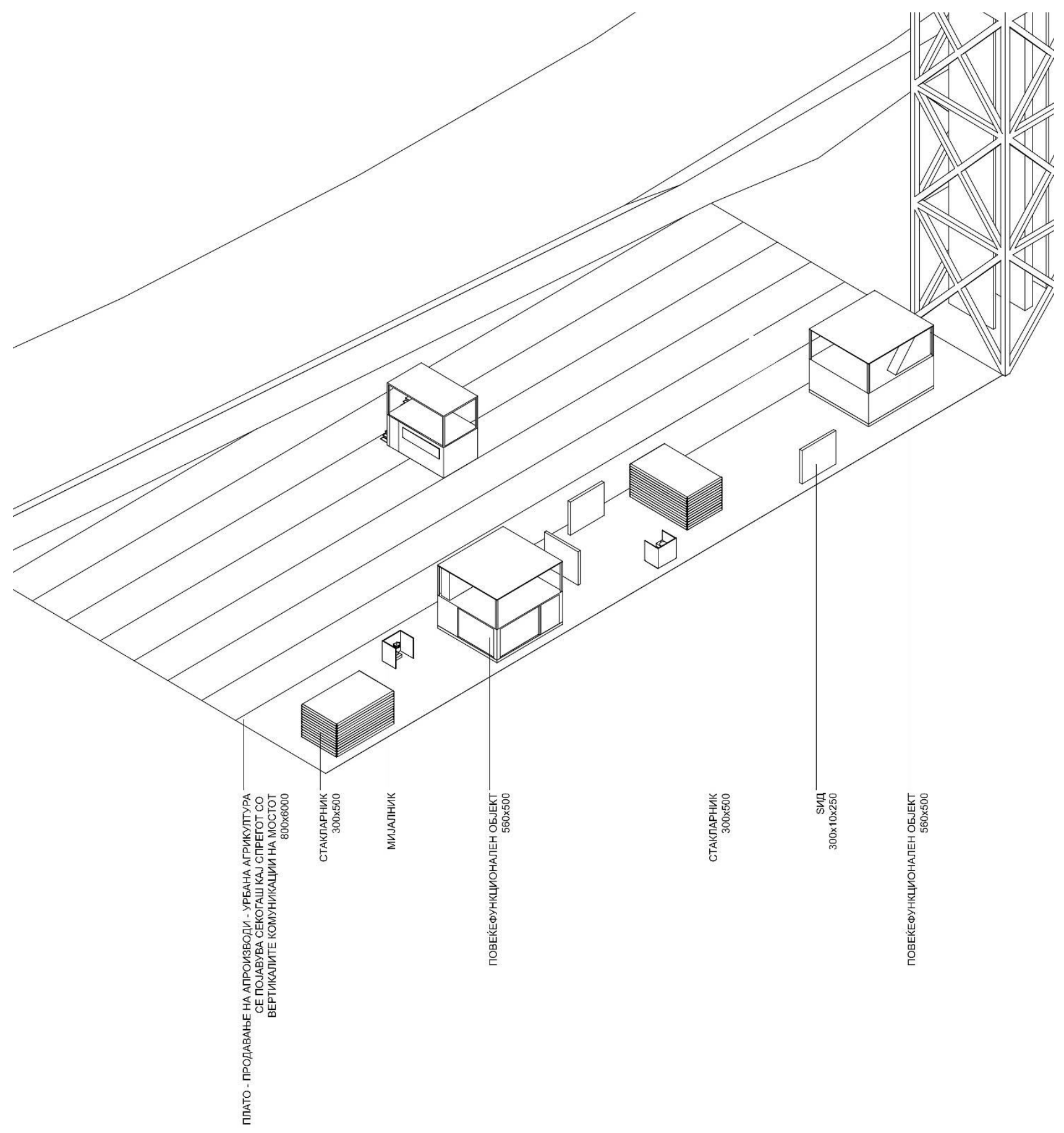

Сл. 41 Аксонометрија на дел од интервенцијата, плато - продажба на производи од урбаната агрикултура 


\section{Паркинг кула / видиковец / резервоар за вода}

Кулата како елемент - точка, се појавува на четири локации, блиску до пристапни улици и покрај основната функција како паркинг кула, има и функција на видиковец, како и резервоар за вода во служба на урбаната агрикултура.

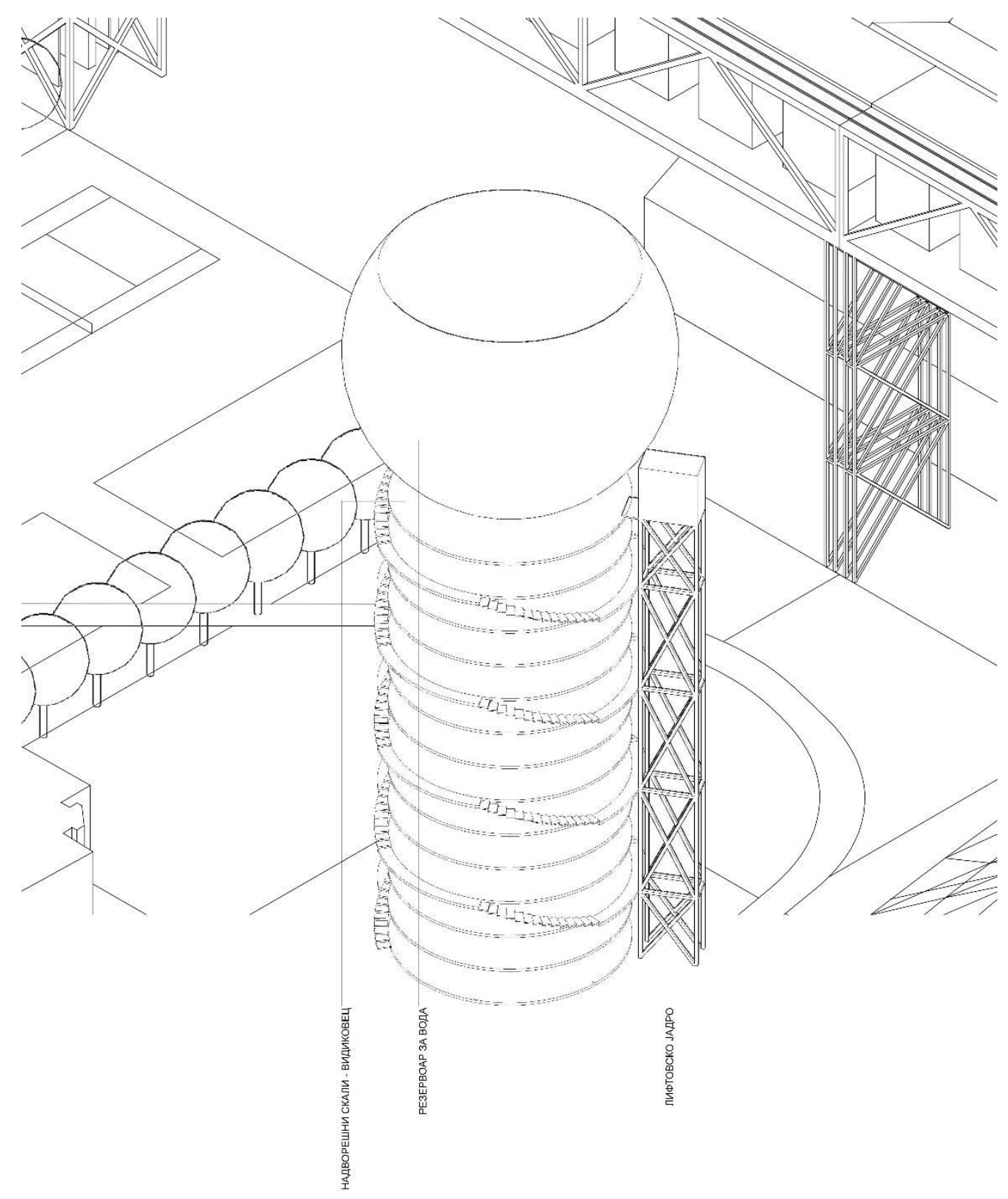

Сл. 42 Аксонометрија на дел од интервенцијата, паркинг кула / видиковец / резервоар за вода 


\section{Заклучок:}

Овој проект ги истражува причините и последиците на просторно-програмското фрагментирање во градот. Фокусирајќи се на источната зона на градот Скопје, која е препознаена како зона на последователно линеарно ширење на градот, поставени се прашањата: на кој начин можат разнородните програмски траки да се интегрираат? Како може да се трансформира и зголеми станбениот капацитет, а притоа да се задржат неговите локални животни вредности?

Преку постапката на инцизија / расекување на градот и суперпонирање на линеарни формации се овозможува програмско и просторно надградување и истовремено поврзување на различните просторно-програмски положби на градот. На тој начин се создава една нова просторна конфигурација, колективна форма, која се однесува на конкретната урбана морфологија и истовремено опстојува независно. Со постапката на расекување можеме да ги согледаме и редефинираме односите помеѓу различните зони на линискиот град, како и причините и последиците од линеарниот раст.

Преку истражувачкиот проект за трансформирање на станбената структура претставена методата на -инцизија-, која ако ја дефинираме холистички, како една целина, претставува интегрирачка, хетерогена, инфраструктура на фррагментите на линеарно - дисконтинуираната урбана морфологија на градот Скопје. Таа интеграција постои од различни аспекти, од морфолошки аспект, со фризичкото поврзување на две важни точки и зоните меѓу нив; од социјален и културен аспект, со создавањето на услови за подигање на свеста, креативноста и 
самоиницијативата на жителите со активен придонес во креирање на сопствената животна средина, како и нов тип на станбена зона која носи нови искуства и предизвици; од еколошки аспект, со внесување на зеленилото во градот во една континуирана линија; од економски аспект, со создавање на еден активен, целосен циклусен процес на садење, одгледување, преработка, пакување и продажба на производи од агрикултурата, од кој бенефираат не само жителите туку и други мали производни капацитети; од рекреативен аспект, создавање на ново искуство и доживување на градот и неговите диверзитети со движење на велосипедско - пешачката патека. Сите овие аспекти, сублимирани заедно, функионираат заедно како една целина и му служат на градот како една интегрирачка, поливалентна инфраструктура. 


\section{Библиографија:}

Alexander, C. (1977) . A Pattern Language. New York: Oxford University Press

Aravena, A. (2010) . Elemental. (A. lacobelli). Germany: Actar

Aureli, P. V. DOGMA (2007) Stop City. (M. Tattara).

Бакалчев, М. проф. Д-р. (2004) . Домување како урбан фррагмент во примерот на Скопје. Необјавена докторска дисертација, Архитектонски Факултет Скопје, Универзитет Св.Кирил и Методиј, Скопје

Brillembourg A. \& Klumpner H. (Urban Think Tank), (http://www.u-tt.com/)

Hertzberger, H. (1993) . Lessons for Students in Architecture. Rotterdam: 010 Publishers

Koolhaas, R. (2011) . Project Japan: Metabolism Talks. (H.Ulrich Obrist). Tachen

Kuroda, J. (2001) . Made in Toyko: Guide book. Tokyo: Kajima Institute Publishing Co

Lin, Z. (2010) . Kenzo Tange and the Metabolist Movement: Urban Utopias of Modern Japan.

New York: Routledge

Lynch, K. (1960) . The Image of the City. Cambridge: The MIT Press

Maas, W. MVRDV (2012). The Verical Village. Rotterdam: 010 Publishers

Maki, F. (1964) . Investigations in collective form. The school of Architecture, Washington University, St. Louis

Rossi, A. (1984) . The Architecture of the city. Cambridge: The MIT Press

Venturi, R. (1977) . Learning from Las Vegas: the forgotten symbolism of architectural form. (D. Scott Brown \& S. Izenour). Cambridge: The MIT Press 


\section{Илустрации:}

Сл. 1 Рим (Google Earth слика)

(Google Earth)

Сл. 2 Мапа на Рим од Г.Ф. Бородино, (1588)

(http://www2.arch.uiuc.edu/courses/arch314/images/012_LateranPalaceandSixtusV/SixtusV2.jpg) ........ 11

Сл. 3 Линеарна екстензија на Мадрид, А.Сорија Мата, (1882)

(http://thedabbler.co.uk/2012/02/norbiton-linear-city/)

Сл. 4 Линеарен град на Н. Миљутин

(http://www.thepolisblog.org/2009/12/imagining-socialist-city.html)

Сл. 5 План за градот Магнитогорск, И. Леонидов (1930)

(http://spec.lib.vt.edu/testdata/BillXs-Scans/chapter2/03316.htm)

Сл. 6 Скица на Ле Корбизје на проектот во Алжир, (1933)

(http://islanddeserters.blogspot.com/2010/01/le-corbusier-plan-obus-alger-1933.html)

Сл. 7 Скица на Ле Корбизје - урбанистичка унификација на француските колонии

(http://publishing.cdlib.org/ucpressebooks/data/13030/jk/ft8c6009jk/figures/ft8c6009jk_00035.gif)......... 16

Сл. 8 Континуиран град за еден милион жители, Алан Боутвел и Мајк Мичел, (1969)

Domus v.470, Milan (1969).....

Сл. 9 Пол Рудолфр - The Lower Manhattan Expressway (1976)

Domus v.558, May (1976)

Сл. 10 Макета од архитектонско-урбанистичко решение на Харлем, ЊуЈорк, САД, 1965 година

(приватен архив на Георги Константиновски)

Сл. 11 Скица - перспектива, поглед кон централниот дел на решението

(приватен архив на Георги Константиновски)

Сл. 12 Скција - перспектива, поглед низ внатрешните пешачки улица

(приватен архив на Георги Константиновски)

Сл. 13 "No Stop City" - Archizoom (1970)

Casabella (1970), под наслов: "City, assembly line of social issues, ideology and theory of the metropolis".

Сл. 14 "No Stop City" - Archizoom (1970)

Casabella (1970), под наслов: "City, assembly line of social issues, ideology and theory of the metropolis".

Сл. 15 "Stop City" - Dogma (2007)

(http://www.dogma.name/projects_list.html).

Сл. 16 "Stop City" - Dogma (2007)

(http://www.dogma.name/projects_list.html). 26 
Сл. 17 Големиот кинески sид, (3 век п.н.е. - 17 век)

(http://famouswonders.com/wp-content/gallery/the-great-wall-of-china/snaking-of-great-wall-ofchina.jpg).

Сл. 18 Рушење на Берлинскиот зид, (1990)

(http://i.dailymail.co.uk/i/pix/2012/08/09/article-2185457-147170CF000005DC-554_964x633.jpg) .....29

Сл. 19 Сцени од филмот “Небо над Берлин”на Вим Вендерс (1987)

(http://thefunambulist.net/2012/01/21/cinema-der-erzahler-the-storyteller-in-wim-wenders-wings-of-

desire/) 30

Сл. 20 Просторен приказ и ситуација, “Ехodus” Рем Колхас и Елија Зенгелис (1972)

приватен архив на Елија Зенгелис

Сл. 21 Лево: Аксијална мапа на Скопје пред воведувањето на железницата (пред 1873) Десно:

Морфолошка анализа - блоковска диференцијација

(архив на катедрата по Урбанизам, Архитектонски фракултет, Скопје)

Сл. 22 Лево: Аксијална мапа на Скопје со воведување на железницата (1873) Десно: Морфолошка анализа - блоковска диференцијација

(архив на катедрата по Урбанизам, Архитектонски факултет, Скопје)

Сл. 23 Лево: Аксијална мапа на Скопје со воведување на новата железничка линија (1888) Десно:

Морфолошка анализа - блоковска диференцијација

(архив на катедрата по Урбанизам, Архитектонски факултет, Скопје)

Сл. 24 Морфолошка анализа на регулациониот план на Д. Леко (1914) - блоковска и улична текстура

(архив на катедрата по урбанизам, Архитектонски фракултет, Скопје) 36

Сл. 25 Морфолошка анализа на планот на Ј. Михајловиќ (1924) - блоковска и улична текстура

(архив на катедрата по Урбанизам, Архитектонски факултет, Скопје)

Сл. 26 Генерален регулационен план на Скопје, Л. Кубеш (1948) Горе: Аксијален план Долу:

Морфолошка анализа - блоковска диференцијација во потесното централно подрачје

(архив на катедрата по Урбанизам, Архитектонски фракултет, Скопје)

Сл. 27 Структурални трансформации на урбаниот грид; од радијален, радијално-концентричен, до линеарен модел

(архив на катедрата по Урбанизам, Архитектонски фракултет, Скопје) .40

Сл. 28 Ситуација на делот од градот одбран за инстражувањето, Скопје-исток..............................43

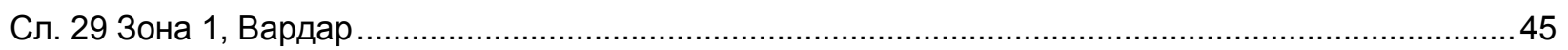

Сл. 30 Зона 2, неформални станбени џепови, населба "Ќерамидница" ........................................... 46

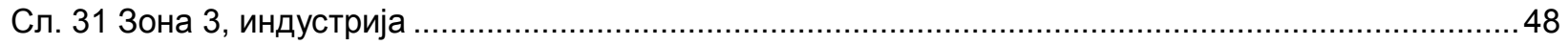

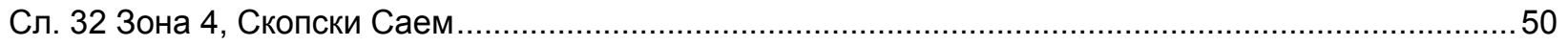

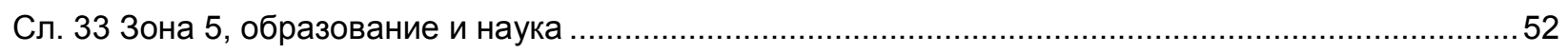

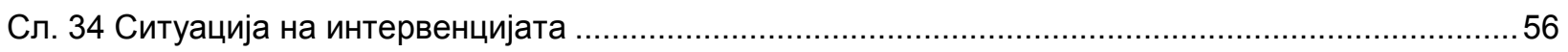


Сл. 35 Аксонометрија на основна конструктивна единица............................................................ 60

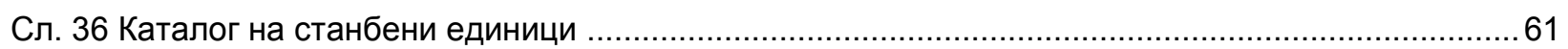

Сл. 37 Аксонометрија на дел од интервенцијата, урбана агрикултура …….................................... 68

Сл. 38 Аксонометрија на дел од интервенцијата, сервисни објекти за урбана агрикултура .............69

Сл. 39 Траекторија на велосипедско-пешачката патека ............................................................... 71

Сл. 40 Аксонометрија на дел од интервенцијата, плато - рекреација, седење, одмор ......................72

Сл. 41 Аксонометрија на дел од интервенцијата, плато - продажба на производи од урбаната

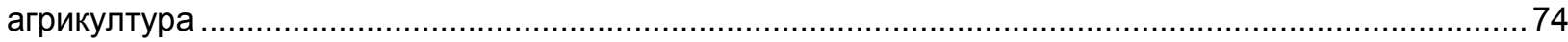

Сл. 42 Аксонометрија на дел од интервенцијата, паркинг кула / видиковец / резервоар за вода ....75 Илустрациите кои не се посебно обележани потекнуваат од авторот. 